\title{
Iron dynamics in a subtropical estuarine tidal marsh: effect of season and vegetation
}

\author{
Min Luo ${ }^{1,2,3}$, Jiafang Huang ${ }^{3}$, Chuan Tong ${ }^{1,3, *}$, Yuxiu Liu ${ }^{3}$, Xun Duan ${ }^{2}$, Yin $\mathrm{Hu}^{2}$ \\ ${ }^{1}$ Postdoctoral Research Station for Ecology, Fujian Normal University, Fuzhou 350007, PR China \\ ${ }^{2}$ School of Environment and Resources, Fuzhou University, Fuzhou 350116, PR China \\ ${ }^{3}$ Key Laboratory of Humid Subtropical Eco-Geographical Processes, Ministry of Education, Fujian Normal University, \\ Fuzhou 350007, PR China
}

\begin{abstract}
To better understand how seasonal change and the presence of plants affect biogeochemical iron (Fe) cycling in tidal marsh sediments, we examined the seasonal dynamics of microbial Fe reduction (FeR) and related Fe speciation from 2012 to 2014 using in situ vegetated and unvegetated mesocosms created with macrobenthos-proof enclosures. The pools of Fe(III) oxides, Fe sulfides, porewater $\mathrm{Fe}^{2+}$, and rates of microbial sulfate reduction (SR) peaked in summer (hot and wet), whereas rates of FeR and non-sulfidic Fe(II) levels peaked in winter (mild and dry). Sedge presence greatly increased the FeR rate, organic matter pools, and Fe(III) oxide levels, but decreased carbon:nitrogen ratios and sulfide abundances. FeR rates were mainly affected by the SR level, and temperature and plant primary productivity had comparable effects on SR rates. The dominant organic carbon mineralization pathway changed from SR in summer to FeR in winter in both vegetated and unvegetated mesocosms. FeR was more important in the vegetated mesocosms than in the unvegetated mesocosms, and seasonal change contributed more to the total variability of each anaerobic pathway than the presence of sedge. Our study reveals that temperature and plants both mediate variations in the organic carbon mineralization pathways of a subtropical estuarine tidal marsh.
\end{abstract}

KEY WORDS: Seasonality $\cdot$ Sedge $\cdot$ Microbial iron reduction - Microbial sulfate reduction - Organic carbon mineralization . Tidal marsh - Min River estuary

\footnotetext{
${ }^{*}$ Corresponding author: tongch@fjnu.edu.cn
}

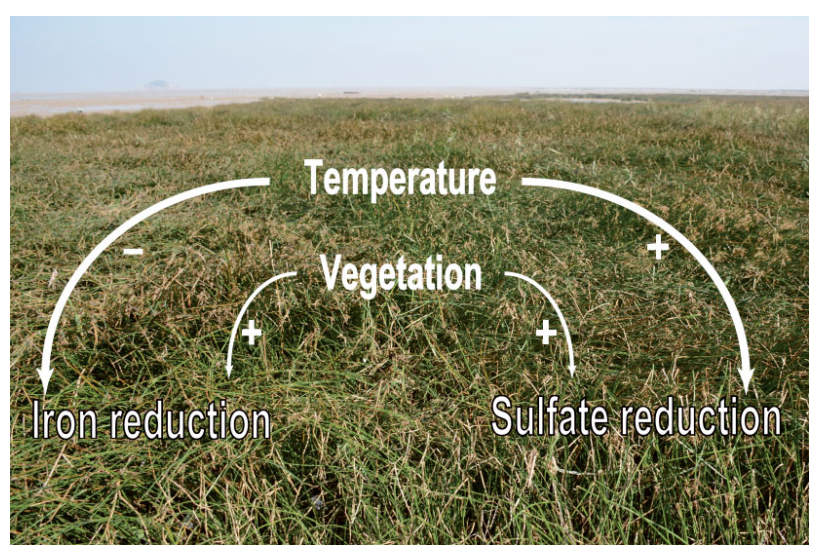

Both temperature and vegetation mediate variations in rates of microbial iron and sulfate reduction of a subtropical estuarine tidal Cyperus malaccensis marsh.

Photo: Min Luo

\section{INTRODUCTION}

Estuarine systems and sheltered coastal areas harbor extensive and highly productive (930-7600 g C $\mathrm{m}^{-2} \mathrm{yr}^{-1}$ ) tidal marshes that receive substantial inputs of autochthonous and allochthonous organic carbon (C) (Schubauer \& Hopkinson 1984, Dame \& Kenny 1986) and are foci of microbial activity, which result in high levels of organic $\mathrm{C}$ mineralization in the sediments (Mitsch \& Gosselink 2000).

Microbial iron reduction (FeR) is a common pathway of organic $\mathrm{C}$ mineralization in many non-sulfidic

(C) The authors 2017. Open Access under Creative Commons by Attribution Licence. Use, distribution and reproduction are unrestricted. Authors and original publication must be credited. 
intertidal systems (Kristensen et al. 2000, 2011, Kostka et al. 2002a, Kristensen \& Alongi 2006, Hyun et al. 2007, Luo et al. 2016). The process is mediated by various Fe(III)-reducing microorganisms, such as Geobacter, Bacillus, Shewanella, and Clostridium (Lovley \& Phillips 1986). Fe(III) can also be abiotically reduced by sulfides, which are primarily generated by microbial sulfate reduction (SR) and ultimately precipitated as $\mathrm{Fe}$ sulfides (e.g. FeS and $\mathrm{FeS}_{2}$ ) (Berner 1970, Canfield 1989, Alongi 1995). FeR not only plays a key role in biogeochemical $\mathrm{Fe}, \mathrm{S}$, and $\mathrm{C}$ cycling, but also has an impact on greenhouse gas emissions and the adsorption and co-precipitation of trace metals that may be present in tidal marsh sediments (Huerta-Diaz \& Morse 1992).

Previous studies on FeR have mainly investigated different habitats (Kristensen et al. 2000, 2011, Gribsholt \& Kristensen 2002, Kostka et al. 2002a, Hyun et al. 2007), vegetation types (Kostka et al. 2002b), salinity or inundation gradients (Neubauer et al. 2005, Luo et al. 2016), or plant rhizospheres (Weiss et al. 2004, 2005). However, relatively few data are available regarding seasonal FeR dynamics in tidal marsh sediments, particularly for systems in the East Asian monsoon region, where hydrothermal conditions differ substantially from those in other coastal areas (Ding \& Chan 2005).

In this study, a seasonal dataset of FeR and Fe speciation in the Shanyu tidal marsh of the Min River estuary, adjoining the East China Sea, was collated. Two sets of in situ mesocosms were established, with and without the indigenous sedge Cyperus malaccensis. Sediments for the mesocosms were collected from the same location to minimize inherent sediment heterogeneity (Holmer et al. 1999, Kristensen \& Alongi 2006). The crab Chiromantes dehaani and mudskipper Periophthalmus modestus are ubiquitous to these tidal marshes, but are unevenly distributed. Because the bioturbation activities of these sediment-dwelling macrofauna also play important roles in sediment Fe and S geochemistry (Kristensen 2001, Gribsholt \& Kristensen 2002, Kristensen \& Alongi 2006, Ferreira et al. 2007), macrobenthosproof enclosures were used to prevent the confounding effects of macrofauna. To accurately identify plant and seasonal effects, the mesocosms had almost identical hydrological conditions (i.e. tide and groundwater). Our strategy was to focus on creating conditions that eliminated spatial heterogeneity and macrobenthos disturbance, rather than completely reproducing natural conditions, and to facilitate quantitative comparisons of the relative effects of season and the presence of sedge plants on Fe dynamics.

\section{MATERIALS AND METHODS}

\section{Site location and characteristics}

The experiments were conducted in the eastern part of the Shanyu tidal marsh (ca. $31.20 \mathrm{~km}^{2}$ ) of the Min River estuary, on the coast of the East China Sea (Fig. 1); the characteristics of this site have been described in detail previously (Tong et al. 2010, Luo et al. 2014, 2016). The Min River estuary experiences a typical subtropical monsoon climate consisting of long, hot, and wet summers (June to September) and short, mild, and dry winters (January to February; Fig. 2). The average annual air temperature is approximately $21^{\circ} \mathrm{C}$, with maximum temperatures in July $\left(30 \pm 1^{\circ} \mathrm{C}\right)$ and minimum temperatures in January $\left(12 \pm 2^{\circ} \mathrm{C}\right)$. Monsoon rains typically occur from March to June, although occasionally heavy precipitation events (typhoons) may occur as late as August. The average rainfall during the wet season (monthly average: $167 \pm 66 \mathrm{~mm}$ ) is much higher than during the dry season (monthly average: $48 \pm 44 \mathrm{~mm}$ ). The tidal marsh is flooded twice daily by semi-diurnal tides with a range of 2.5-6.0 m (Luo et al. 2014) and consequently is subjected to frequent periods of inundation (from $26 \%$ of the marsh in February to $31 \%$ in October). Inundation frequency is relatively stable over the course of a year $(p>0.05$, coefficient of variation $[\mathrm{CV}]<5 \%$ ).

\section{Experimental design}

The mesocosms were established using specially designed polyethylene tanks (length: $60 \mathrm{~cm}$; width: $40 \mathrm{~cm}$; height: $36 \mathrm{~cm}$ ) in which 2 columns of slots were drilled into the sides and bottoms to enable interactions with the surrounding sediments (Fig. 1c). Each tank was covered with $0.15 \mathrm{~mm}$ mesh filter fabric, and nylon-wire fencing was placed around the perimeter of each tank to prevent macrobenthos incursions. On 6 and 7 February 2012, 32 tanks were buried in the sediments with the nylon-wire fence $\sim 20 \mathrm{~cm}$ above the surrounding ground level. The tanks were arranged in 2 lines $20-30 \mathrm{~cm}$ apart (Fig. 1d). Sediment was collected from a tidal creek bank $20 \mathrm{~m}$ away and was then homogenized and passed through a $2 \mathrm{~mm}$ sieve to exclude any macrobenthos. Twenty of the tanks were uniformly planted with young Cyperus malaccensis shoots (density: $100 \mathrm{~m}^{-2}$; height: $\left.5-10 \mathrm{~cm}\right) 1 \mathrm{wk}$ following sediment transfer, and are hereafter termed 'vegetated mesocosms'; the other 12 tanks had no plants, and are 


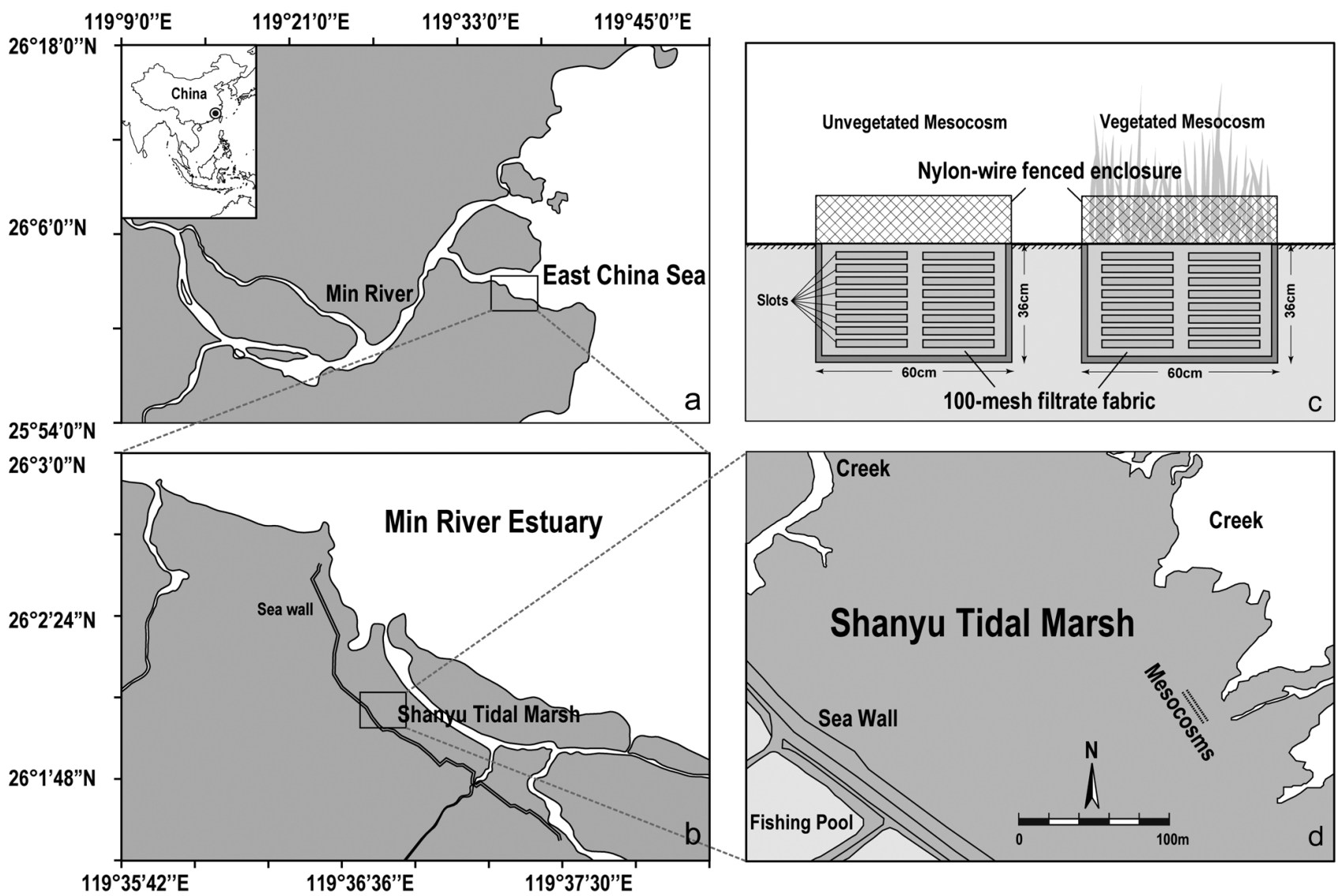

Fig. 1. $(\mathrm{a}, \mathrm{b}, \mathrm{d})$ Location of the mesocosms. (c) Design of the vegetated and unvegetated mesocosms

hereafter termed 'unvegetated mesocosms'. The mesocosms were then exposed to the in situ environment for 5 mo before sampling was initiated. The sampling periods were July and November 2012, February, April, June, and October 2013, and January 2014. Sediment excavated during sampling was returned to the mesocosms to avoid a collapse of the mesocosms.

\section{Ecological measurements}

Within three random plots $(30 \mathrm{~cm}$ $\times 30 \mathrm{~cm}$ ) among the vegetated mesocosms, all standing plant material

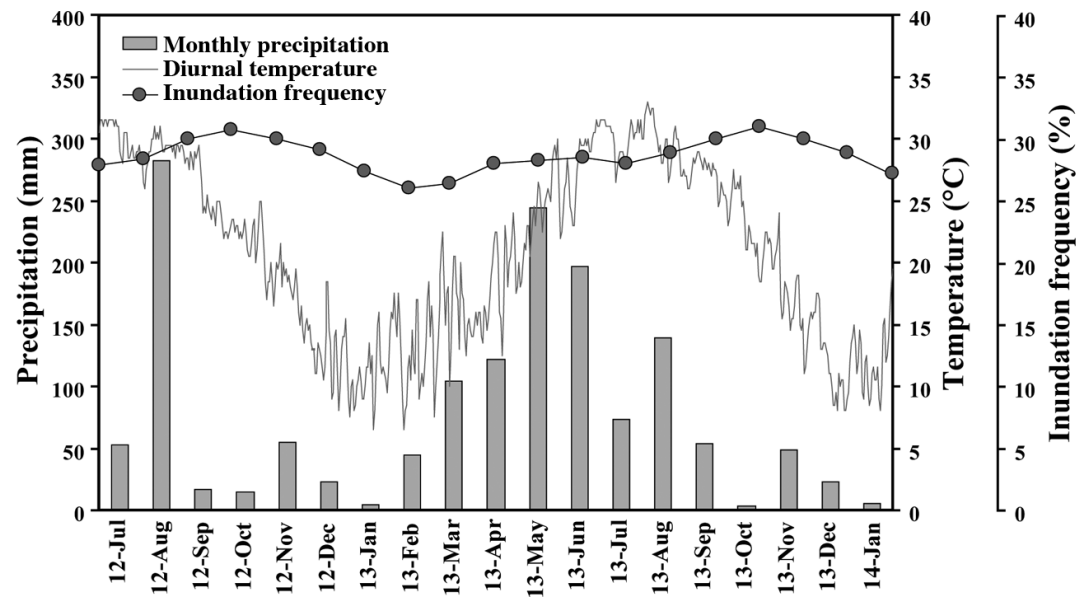

Fig. 2. Monthly precipitation, diurnal temperature, and monthly inundation frequency at the study site in the Min River estuary, East China Sea, during 2012-2014

(including live and dead roots) was harvested for aboveground biomass and all the sediments were washed in large $0.25 \mathrm{~mm}$ filter fabric bags to obtain belowground biomass during each sampling period. Biomasses were measured after the plant materials had been oven-dried at $70^{\circ} \mathrm{C}$ for $48 \mathrm{~h}$. Net primary productivity was calculated as the difference in total biomass (the sum of above- and belowground biomasses) between early in each sampling month and toward the end of that month (Wang et al. 2015). 


\section{Sample collection and preparation}

In each sampling period, 5-7 sediment cores were taken from the $0-30 \mathrm{~cm}$ layer during low neap tide. This depth was chosen because the most dramatic impacts of seasonal change would be expected to occur in surface sediments (Böttcher et al. 2000, Kostka et al. 2002a). Cores were taken using polycarbonate corers (internal diameter: $5 \mathrm{~cm}$; length: $50 \mathrm{~cm}$ ) that were immediately capped at both ends following sampling and placed in vacuumized plastic bags. The samples were stored on ice and taken to the laboratory within $1 \mathrm{~h}$ of collection. In the laboratory, pretreatment of the sediment and porewater samples was conducted in a $\mathrm{N}_{2}$-filled glove bag (AtmosBag, Sigma-Aldrich). Cores were extruded stepwise, and samples were obtained from the $0-2$, $2-4,4-6,6-8,8-10,12-14,20-22$, and 28-30 cm layers. Sediment samples from each layer were homogenized and passed through a $2 \mathrm{~mm}$ sieve to remove roots. Porewater was extracted by centrifuging $(4000 \times g$ for $20 \mathrm{~min})$ for $\mathrm{pH}$, chloride $\left(\mathrm{Cl}^{-}\right)$, and $\mathrm{SO}_{4}{ }^{2-}$ analysis, and by in situ Rhizon samplers for dissolved organic carbon (DOC), $\mathrm{Fe}^{2+}$, and aqueous sulfide concentrations $\left(\sum \mathrm{H}_{2} \mathrm{~S}=\mathrm{H}_{2} \mathrm{~S}_{(\mathrm{g})}+\mathrm{HS}^{-}+\mathrm{S}^{2-}+\right.$ $\mathrm{S}_{X}{ }^{2-}$; Bull \& Taillefert 2001) analysis. The porewater samples were filtered through $0.45 \mu \mathrm{m}$ syringe filters (Acrodisc, Pall) and drained into $10 \mathrm{ml}$ glass vials; the filters used for $\mathrm{Fe}^{2+}$ and DOC analyses were prewashed with diluted hydrogen chloride ( $\mathrm{HCl}$ ). For $\sum \mathrm{H}_{2} \mathrm{~S}$ determination, aliquots of the porewater samples were fixed in $20 \%$ zinc acetate, effervesced with $\mathrm{N}_{2}$, and stored in bottles capped with Teflon-coated butyl rubber septa. The sediment and porewater samples were stored at $4{ }^{\circ} \mathrm{C}$ until analysis (within $7 \mathrm{~d}$ ).

\section{Sediment and porewater geochemistry}

Sediment total organic carbon (TOC) and total nitrogen (TN) levels were determined using a combustion analyzer (Vario EL III, Elementar), with an error margin lower than $0.3 \%$. Carbonate was removed with $10 \% \mathrm{HCl}$ prior to TOC determination. Solid-phase Fe species (including Fe(II), amorphous Fe(III), and crystalline Fe(III)) were extracted with $0.5 \mathrm{M}$ deoxygenated $\mathrm{HCl}, 0.5 \mathrm{M}$ deoxygenated $\mathrm{HCl}+$ hydroxylamine $\left(0.1 \mathrm{~g} \mathrm{ml}^{-1}\right)$, and citrate-bicarbonatedithionite (0.35 M glacial acetic acid/0.2 M sodium citrate, buffered with $50 \mathrm{gl}^{-1}$ sodium dithionite) and analyzed by the sequential extraction method developed by Kostka \& Luther (1994) and the 1,10- phenanthroline method (APHA 2005). Solid-phase sulfur species (including acid-volatile sulfide [AVS] and chromium-reducible sulfide [CRS]) were determined by the sequential extraction method developed by Burton et al. (2008). Estimates of FeS and $\mathrm{FeS}_{2}$ were based on the stoichiometric relationship between $\mathrm{Fe}$ and $\mathrm{S}$ in terms of differences in AVS and $\sum \mathrm{H}_{2} \mathrm{~S}\left(\mathrm{Fe}: \mathrm{S}=1: 1\right.$ in AVS $\left.-\sum \mathrm{H}_{2} \mathrm{~S}\right)$ and CRS (Fe:S $=1: 2$ in CRS) (Johnston et al. 2011). Non-sulfidic Fe(II) levels were calculated based on the difference in Fe(II) and Fe sulfides (non-sulfidic Fe(II) $=\mathrm{Fe}(\mathrm{II})-\mathrm{FeS}-$ $\mathrm{FeS}_{2}$ ). Further details can be found in previous studies (e.g. Luo et al. 2016).

Porewater $\mathrm{pH}$ was measured using a benchtop $\mathrm{pH}$ meter (Orion 3-Star Plus, Thermo Fisher Scientific), total alkalinity was determined using bromophenol blue method (detection limit $=1 \mu \mathrm{M}$; SD = 1\%) as described by Sarazin et al. (1999), and DOC concentrations were analyzed using an Aurora 1030C TOC analyzer (OI Analytical). The 1,10-phenanthroline method (detection limit $=1 \mu \mathrm{M} ; \mathrm{SD}=1 \%$; APHA 2005) was used to analyze porewater $\mathrm{Fe}^{2+}$ concentrations, and $\Sigma \mathrm{H}_{2} \mathrm{~S}$ was determined by the methylene blue method (detection limit $=1 \mu \mathrm{M} ; \mathrm{SD}=1 \%$; Cline 1969). Estimates of total carbon dioxide $\left(\mathrm{TCO}_{2}=\right.$ $\mathrm{CO}_{2(\mathrm{aq})}+\mathrm{HCO}_{3}{ }^{-}+\mathrm{CO}_{3}{ }^{2-}$ ) were then derived from the total alkalinity, porewater $\mathrm{pH}$, and $\sum \mathrm{H}_{2} \mathrm{~S}$ values (Stumm et al. 1996). Porewater $\mathrm{SO}_{4}{ }^{2-}$ and $\mathrm{Cl}^{-}$concentrations were determined by ion chromatography (Dionex ICS-2000). Changes in $\mathrm{SO}_{4}{ }^{2-}$ concentrations $\left(\Delta \mathrm{SO}_{4}{ }^{2-}\right)$, which reflect the net $\mathrm{SO}_{4}{ }^{2-}$ consumption, were calculated using Eq. (1) (Gribsholt \& Kristensen 2002, Beck et al. 2008) assuming constant salinity over time:

$$
\Delta \mathrm{SO}_{4}^{2-}=\left(\mathrm{SO}_{4}^{2-}\right)_{\mathrm{pw}}-\left(\mathrm{Cl}^{-}\right)_{\mathrm{pw}} \times \frac{\left(\mathrm{SO}_{4}^{2-}\right)_{\mathrm{sw}}}{\left(\mathrm{Cl}^{-}\right)_{\mathrm{sw}}}
$$

where $\left(\mathrm{SO}_{4}{ }^{2-}\right)_{\mathrm{pw}}$ and $\left(\mathrm{Cl}^{-}\right)_{\mathrm{pw}}$ are the $\mathrm{SO}_{4}{ }^{2-}$ and $\mathrm{Cl}^{-}$ concentrations in porewater, respectively, and $\left(\mathrm{SO}_{4}{ }^{2-}\right)_{\mathrm{sw}}$ and $\left(\mathrm{Cl}^{-}\right)_{\mathrm{sw}}$ are the concentrations of $\mathrm{SO}_{4}{ }^{2-}$ and $\mathrm{Cl}^{-}$in seawater, respectively. The molar ratio of $\left(\mathrm{SO}_{4}{ }^{2-}\right)_{\mathrm{sw}} /\left(\mathrm{Cl}^{-}\right)_{\mathrm{sw}}$ is equal to $5.14 \times 10^{-2}$ in sea surface waters (Gribsholt \& Kristensen 2002). A negative $\Delta \mathrm{SO}_{4}{ }^{2-}$ indicates the removal of $\mathrm{SO}_{4}{ }^{2-}$, presumably by $\mathrm{SR}$, whereas a positive $\Delta \mathrm{SO}_{4}{ }^{2-}$ indicates $\mathrm{SR}$ being offset by sulfide reoxidation (Thamdrup et al. 1994, Gribsholt \& Kristensen 2002, Beck et al. 2008).

\section{Rate measurements}

Incubation experiments were conducted in a $\mathrm{N}_{2}$ filled glove bag and are described in detail in a 
previous study (Luo et al. 2016). Briefly, fresh sediment samples from each depth interval were thawed, pooled, mixed thoroughly, and then loaded into $50 \mathrm{ml}$ glass jars with no head space. The jars were capped tightly with Teflon-coated butyl rubber septa and stored in the dark at field temperature for $72 \mathrm{~h}$. At regular intervals $(24 \mathrm{~h}), 5$ to 7 jars were sacrificed for rate measurements. Anaerobic organic carbon mineralization rates (CMR) were determined based on the accumulation of porewater $\mathrm{TCO}_{2}$ over time. The FeR rate (FeRR) was estimated from the generation of non-sulfidic $\mathrm{Fe}(\mathrm{II})$ and porewater $\mathrm{Fe}^{2+}$ over time, and the production of AVS and CRS over time was used to determine the SR rate (SRR). Our SRR estimates should be accepted with some caution, given that the method may discount sulfide reoxidation resulting in underestimates of the actual SRR (for more details and further discussion, see Luo et al. 2016). The contributions of FeR (FeR\%) and SR (SR\%) are presented in $\mathrm{C}$ units using the theoretical stoichiometry of C:Fe $=1: 4$ and $\mathrm{S}: \mathrm{C}=2: 1$ (Kristensen et al. 2000, 2011, Kostka et al. 2002a, Hyun et al. 2007, 2009).

\section{Data analysis}

The data were tested for homogeneity of variance and normality, then log transformed if necessary before further statistical analysis. Differences in ecological and geochemical properties among sediment depths, seasons, and mesocosms (vegetated versus unvegetated) were tested by 1 -way ANOVAs. The effects of plant presence, season, and their interaction on FeR, SR, CMR, FeR\%, and SR\% were examined by 2-way ANOVAs. Individual means (within seasons or mesocosms) were compared by least significant difference post-hoc tests. DOC, $\Delta \mathrm{SO}_{4}{ }^{2-}, \Sigma \mathrm{H}_{2} \mathrm{~S}$, amorphous $\mathrm{Fe}(\mathrm{III})$, crystalline $\mathrm{Fe}(\mathrm{III}), \mathrm{FeS}$, and $\mathrm{FeS}_{2}$ levels in the vegetated and unvegetated mesocosms were compared using paired-sample $t$-tests. Data are presented as mean \pm $\mathrm{SD}$, unless indicated otherwise. Bivariate correlations among ecological, geochemical, and environmental properties, Fe species, and anaerobic metabolism were tested using the Pearson correlation coefficient (r). The relative importance of temperature, precipitation, and primary productivity on SR was determined by stepwise multiple linear regression. The CV is the ratio of the SD to the mean. Significance was set at $\alpha=0.05$ for all tests, which were performed in PASW Statistics 22.0.

\section{RESULTS}

\section{Ecological properties}

Cyperus malaccensis grew vigorously in the vegetated mesocosms 5 mo after planting, and the plant biomasses were comparable with the results of previous studies (Wang et al. 2015). Season significantly affected both biomass and primary productivity in the vegetated mesocosms (Tables 1 \& 2). Aboveground biomass was significantly higher in the summer $\left(1099 \pm 117 \mathrm{~g} \mathrm{~m}^{-2}\right)$ than in the other seasons, whereas belowground biomass was significantly higher in the autumn $\left(2743 \pm 319 \mathrm{~g} \mathrm{~m}^{-2}\right)$ than in the other seasons. Primary productivity differed significantly among the seasons (Table 2), increasing from spring $\left(4.93 \pm 1.33 \mathrm{~g} \mathrm{~m}^{-2} \mathrm{~d}^{-1}\right)$ to summer $(8.98 \pm 2.17 \mathrm{~g}$ $\left.\mathrm{m}^{-2} \mathrm{~d}^{-1}\right)$, and decreasing from autumn $(-0.41 \pm 1.00 \mathrm{~g}$ $\left.\mathrm{m}^{-2} \mathrm{~d}^{-1}\right)$ to winter $\left(-4.67 \pm 1.93 \mathrm{~g} \mathrm{~m}^{-2} \mathrm{~d}^{-1}\right.$; Table 1$)$.

\section{Sediment geochemistry}

Both TOC and TN levels ( $\mu \mathrm{mol} \mathrm{g} \mathrm{g}^{-1}$ dry weight [dw]) were higher in the vegetated mesocosms (TOC: 2.19-3.03; TN: $0.19-0.27)$ than in the unvegetated mesocosms (TOC: 1.45-1.81; TN: 0.15-0.18; Tables 1 $\& 2)$. Higher $\mathrm{C}: \mathrm{N}$ ratios were observed in the vegetated mesocosms (range: 11.2-12.2) than in the unvegetated mesocosms (range: 8.6-10.4; Table 2). Season had a significant effect on TOC and TN pools in the vegetated mesocosms, with higher values being recorded during winter and summer than during spring and autumn. In contrast, it had no effect on TOC and TN pools in the unvegetated mesocosms (Table 2). There were no significant differences in the $\mathrm{C}: \mathrm{N}$ ratio among the sampling periods in both types of mesocosms (Table 2).

\section{Porewater geochemistry}

Porewater $\mathrm{pH}$ ranged from 6.4 to 7.1 and from 6.7 to 7.3 in the vegetated and unvegetated mesocosms, respectively (Fig. 3a), but the difference between mesocosms was not significant, nor were significant differences observed among seasons or sediment layers (Table 2).

Total alkalinity had a broader range and was significantly higher in the vegetated mesocosms (range: 6.9-21.6 $\mathrm{mM}$ ) than in the unvegetated mesocosms (range: 4.7-15.0 mM; Fig. 3b). Total alkalinity was significantly higher during winter than during the 
Table 1. Ecological and geochemical properties of surface sediments $(0-30 \mathrm{~cm})$ in vegetated and unvegetated mesocosms at the study site in the Min River estuary, southeastern China, during 2012-2014. Values are mean \pm SD. TOC: total organic carbon; TN: total nitrogen; dw: dry weight; na: not applicable

\begin{tabular}{|c|c|c|c|c|c|c|}
\hline & $\begin{array}{l}\text { Aboveground } \\
\text { biomass }\left(\mathrm{g} \mathrm{m}^{-2}\right)\end{array}$ & $\begin{array}{l}\text { Belowground } \\
\text { biomass }\left(\mathrm{g} \mathrm{m}^{-2}\right)\end{array}$ & $\begin{array}{l}\text { Primary productivity } \\
\qquad\left(\mathrm{g} \mathrm{m}^{-2} \mathrm{~d}^{-1}\right)\end{array}$ & $\begin{array}{c}\text { TOC } \\
\left(\mu \mathrm{mol} \mathrm{g}{ }^{-1} \mathrm{dw}\right)\end{array}$ & $\begin{array}{c}\mathrm{TN} \\
\left(\mu \mathrm{mol} \mathrm{g}{ }^{-1} \mathrm{dw}\right)\end{array}$ & $\mathrm{C}: \mathrm{N}$ ratio \\
\hline \multicolumn{7}{|l|}{ July 2012} \\
\hline Vegetated & $1062 \pm 71$ & $2311 \pm 136$ & $8.64 \pm 1.22$ & $2.75 \pm 0.09$ & $0.23 \pm 0.01$ & $12.1 \pm 0.9$ \\
\hline Unvegetated & na & na & na & $1.58 \pm 0.07$ & $0.16 \pm 0.01$ & $10.0 \pm 0.4$ \\
\hline \multicolumn{7}{|c|}{ November 2012} \\
\hline Vegetated & $589 \pm 26$ & $2640 \pm 211$ & $-0.80 \pm 0.55$ & $2.35 \pm 0.16$ & $0.21 \pm 0.01$ & $11.2 \pm 0.5$ \\
\hline Unvegetated & na & na & na & $1.50 \pm 0.10$ & $0.16 \pm 0.01$ & $9.5 \pm 0.8$ \\
\hline \multicolumn{7}{|l|}{ February 2013} \\
\hline Vegetated & $385 \pm 42$ & $2071 \pm 143$ & $-5.32 \pm 1.54$ & $3.03 \pm 0.09$ & $0.27 \pm 0.01$ & $11.3 \pm 0.4$ \\
\hline Unvegetated & na & na & na & $1.55 \pm 0.13$ & $0.15 \pm 0.01$ & $10.4 \pm 0.5$ \\
\hline \multicolumn{7}{|l|}{ April 2013} \\
\hline Vegetated & $465 \pm 63$ & $1845 \pm 105$ & $4.93 \pm 0.77$ & $2.19 \pm 0.09$ & $0.19 \pm 0.01$ & $11.5 \pm 0.1$ \\
\hline Unvegetated & na & na & na & $1.81 \pm 0.05$ & $0.18 \pm 0.01$ & $10.1 \pm 0.2$ \\
\hline \multicolumn{7}{|l|}{ June 2013} \\
\hline Vegetated & $1135 \pm 71$ & $2502 \pm 94$ & $9.32 \pm 1.52$ & $2.84 \pm 0.13$ & $0.25 \pm 0.02$ & $11.7 \pm 1.3$ \\
\hline Unvegetated & na & na & na & $1.45 \pm 0.21$ & $0.17 \pm 0.02$ & $8.6 \pm 0.5$ \\
\hline \multicolumn{7}{|l|}{ October 2013} \\
\hline Vegetated & $756 \pm 70$ & $2845 \pm 173$ & $-0.02 \pm 0.61$ & $2.42 \pm 0.39$ & $0.20 \pm 0.03$ & $12.2 \pm 0.3$ \\
\hline Unvegetated & na & na & na & $1.64 \pm 0.14$ & $0.16 \pm 0.02$ & $10.4 \pm 0.4$ \\
\hline \multicolumn{7}{|l|}{ January 2014} \\
\hline Vegetated & $321 \pm 35$ & $2354 \pm 172$ & $-4.02 \pm 0.55$ & $2.89 \pm 0.27$ & $0.26 \pm 0.05$ & $11.6 \pm 1.2$ \\
\hline Unvegetated & na & na & na & $1.55 \pm 0.13$ & $0.15 \pm 0.01$ & $10.4 \pm 0.1$ \\
\hline
\end{tabular}

Table 2. Summary of 1-way ANOVA and paired-sample $t$-tests of the effects of plant, season, and depth on ecological properties, sediment and porewater geochemistry, and iron (Fe) speciation in the Min River estuary, East China Sea, during 2012-2014. TOC: total organic carbon; TN: total nitrogen; DOC: dissolved organic carbon; V: data in the vegetated mesocosms; $\mathrm{U}$ : data in the unvegetated mesocosms; -: no data

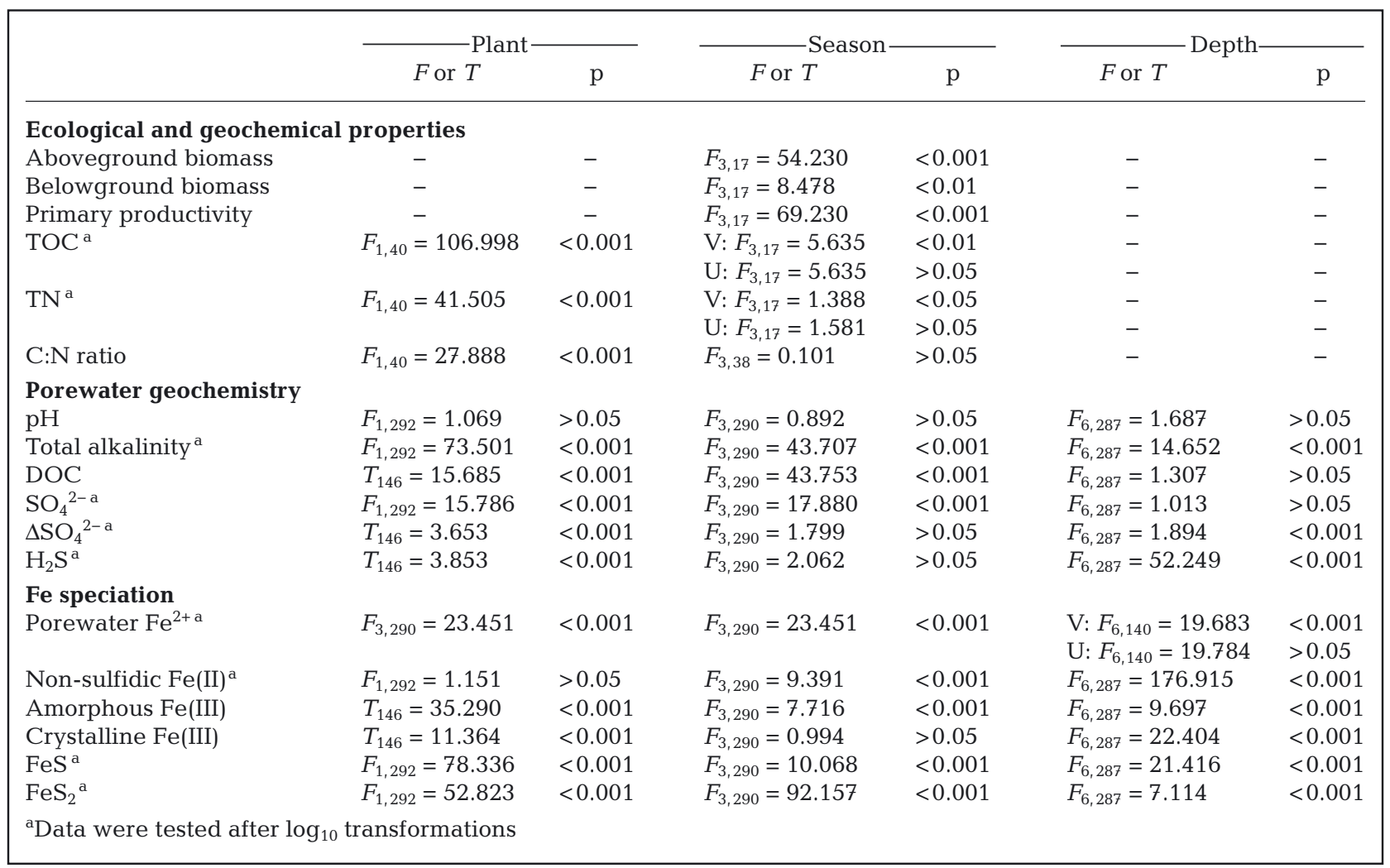



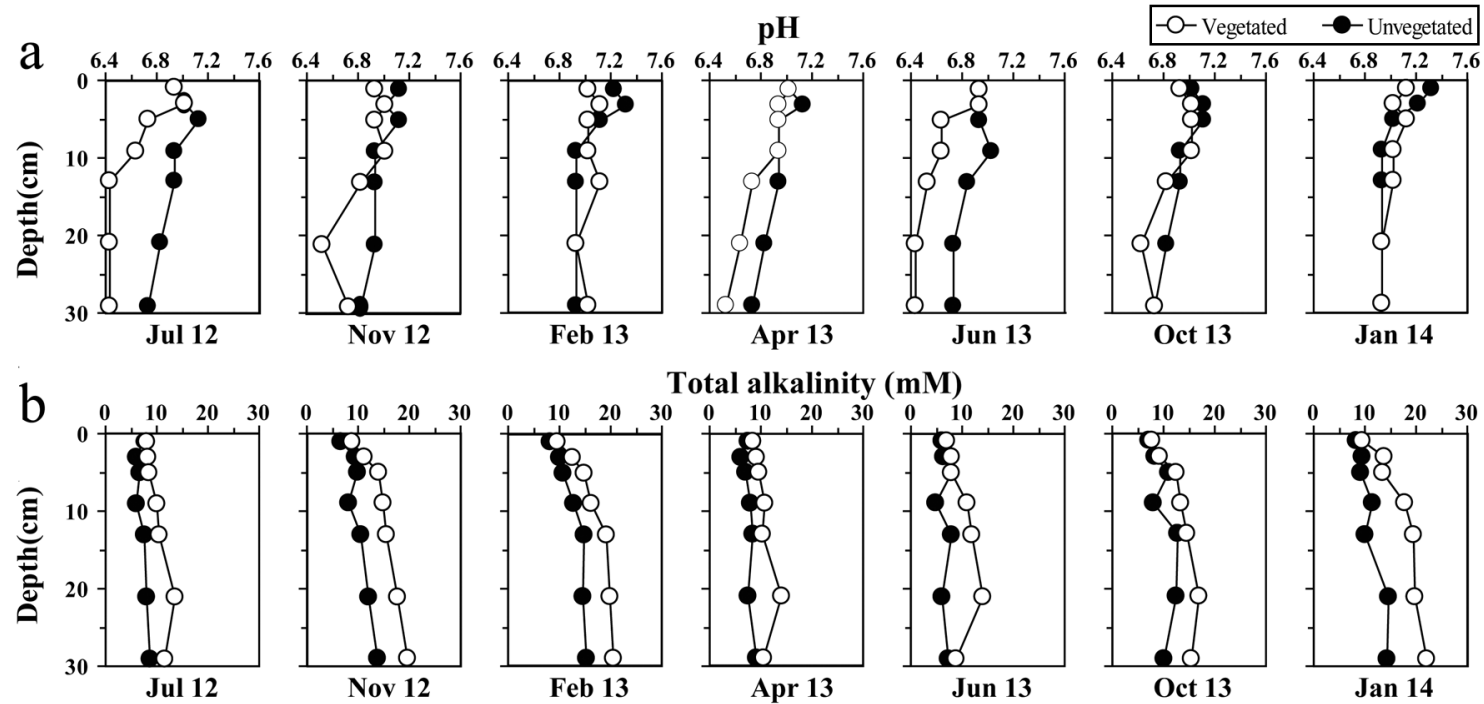

Total alkalinity $(\mathrm{mM})$
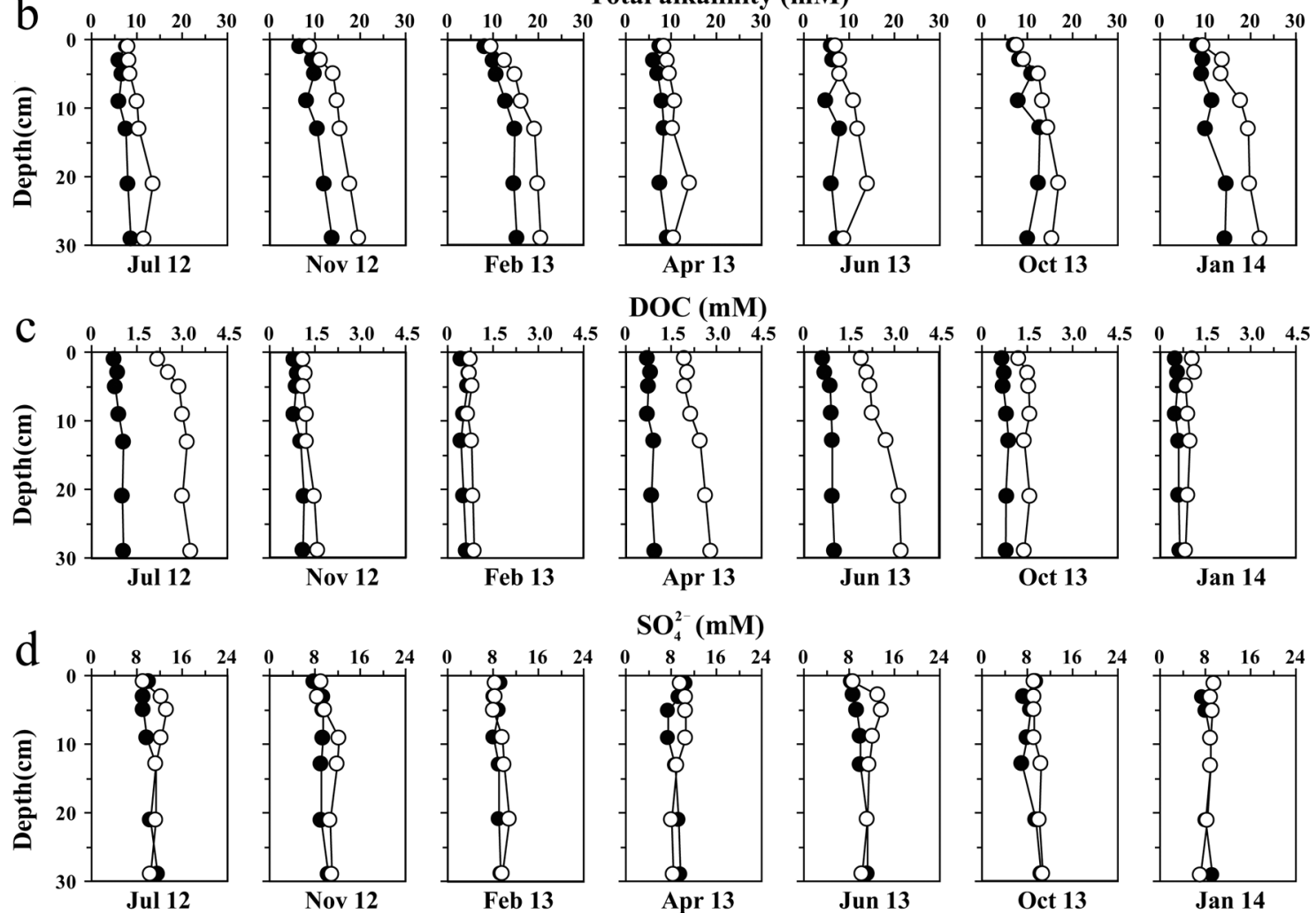

$\mathrm{SO}_{4}^{2-}(\mathrm{mM})$
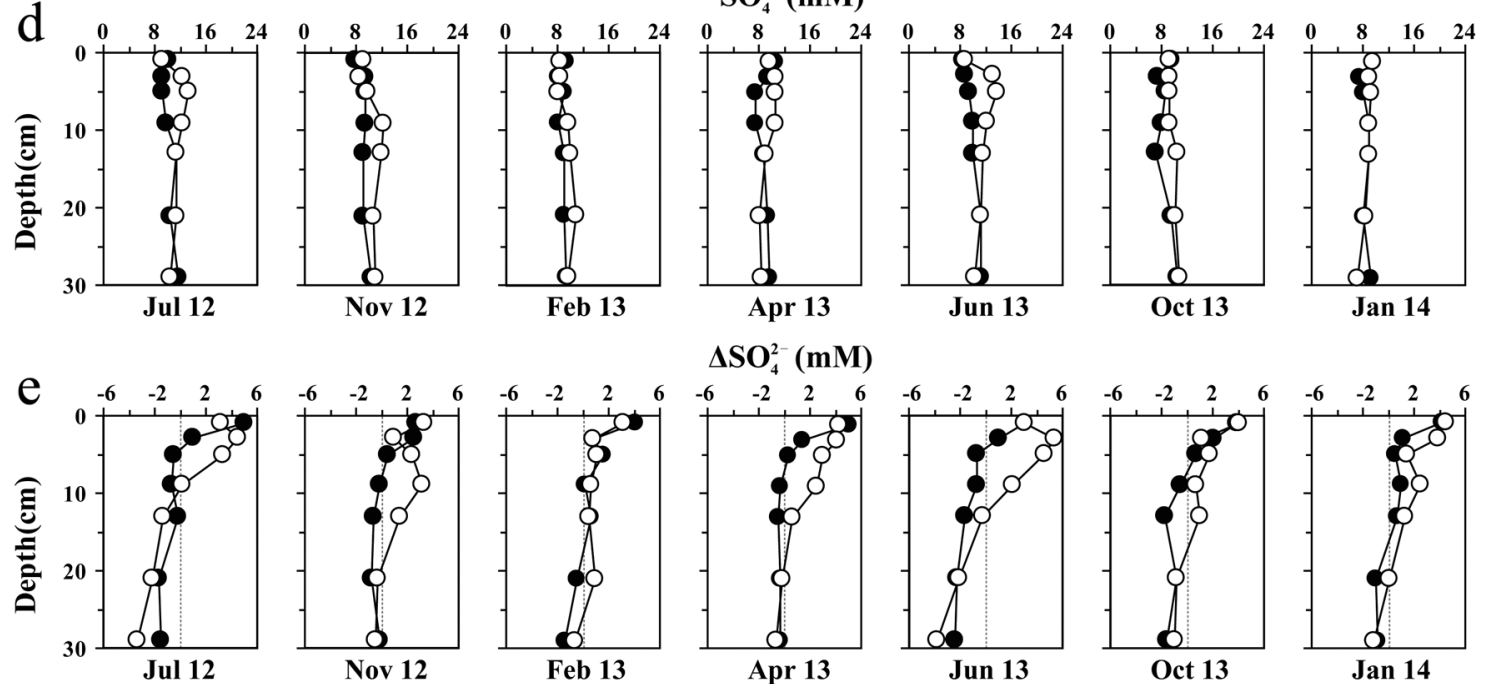

$\Delta \mathrm{SO}_{4}^{2-}(\mathrm{mM})$
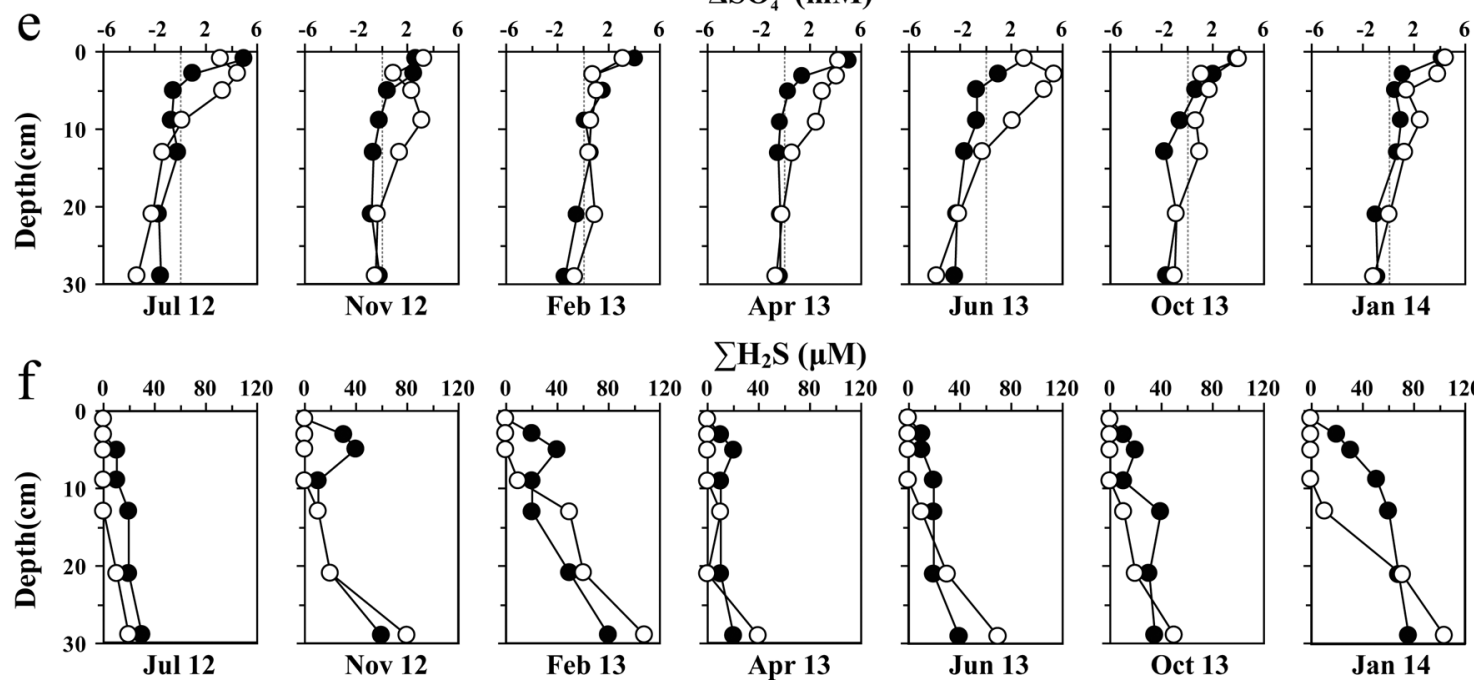

$\sum \mathbf{H}_{2} \mathbf{S}(\mu \mathrm{M})$
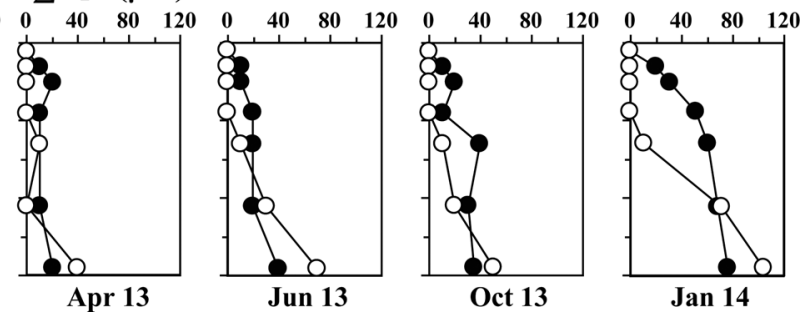

Fig. 3. Depth-specific porewater chemistry in vegetated and unvegetated mesocosms in the tidal marsh sediments of the Min

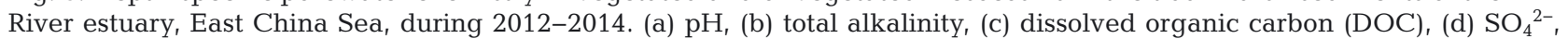
(e) $\Delta \mathrm{SO}_{4}{ }^{2-}$, and (f) $\sum \mathrm{H}_{2} \mathrm{~S}$ 
other seasons and generally increased with depth in both types of mesocosms (Table 2).

The vegetated mesocosms typically had a larger DOC pool (range: $0.5-3.3 \mathrm{mM}$ ) than the unvegetated mesocosms (range: $0.4-1.0 \mathrm{mM}$ ) in all sediment layers in every season (Fig. 3c). Seasonal changes in DOC levels occurred in the 2 types of mesocosms, both of which showed maximum levels in summer and minimum levels in winter (Table 2). Sediment depth did not appear to affect DOC (Table 2).

Porewater $\mathrm{SO}_{4}{ }^{2-}$ concentrations were significantly higher in the vegetated mesocosms (range: 7.3$13.6 \mathrm{mM}$ ) than in the unvegetated mesocosms (range: 7.2-11.6 mM) (Fig. 3d) and were higher in the summer than in the other seasons. Sediment depth did not appear to affect porewater $\mathrm{SO}_{4}{ }^{2-}$ (Table 2). A positive $\Delta \mathrm{SO}_{4}{ }^{2-}$ was observed in the $0-10 \mathrm{~cm}$ and $0-4 \mathrm{~cm}$ sediment layers of the vegetated and unvegetated mesocosms, respectively, whereas a negative $\Delta \mathrm{SO}_{4}{ }^{2-}$ was observed in the lower layers (Fig. 3e). Seasonal differences in $\Delta \mathrm{SO}_{4}{ }^{2-}$ were not observed in any mesocosm (Table 2).

Porewater $\Sigma \mathrm{H}_{2} \mathrm{~S}$ was not detected in the upper $0-2 \mathrm{~cm}$ and $0-13 \mathrm{~cm}$ layers of the unvegetated and vegetated mesocosms, respectively, but generally increased with depth below these layers. Porewater $\sum \mathrm{H}_{2} \mathrm{~S}$ was significantly higher in the unvegetated mesocosms (range: 0-81 $\mu \mathrm{M}$ ) than in the vegetated mesocosms (range: $0-110 \mu \mathrm{M}$, Fig. 3f), but did not differ among seasons (Table 2).

\section{Fe speciation}

Porewater $\mathrm{Fe}^{2+}$ was lowest during the winter. In the vegetated mesocosms, porewater $\mathrm{Fe}^{2+}$ gradually increased with depth from 0.0 to $2.4 \mathrm{mM}$ (Fig. 4a), but did not do so in the unvegetated mesocosms, where it remained at very low levels (range: 0 to $0.3 \mathrm{mM}$; Table 2).

The vegetated and unvegetated mesocosms did not differ in non-sulfidic Fe(II) levels (ranges: 12-216 $\mu \mathrm{mol}$ $\mathrm{g}^{-1} \mathrm{dw}$ and 6-173 $\mu \mathrm{mol} \mathrm{g}^{-1} \mathrm{dw}$, respectively; Fig. $4 \mathrm{~b}$ ), which significantly increased with depth in both mesocosms throughout the year (Table 2). The levels peaked during the winter in both mesocosms, and were significantly different from those during the other seasons (Table 2).

Crystalline Fe(III) was more abundant than amorphous Fe(III) throughout the year (Fig. 4c,d). Amorphous Fe(III) peaked during the summer, but season did not affect crystalline Fe(III) (Table 2). There were larger pools of both amorphous and crystalline Fe(III) oxide in the vegetated mesocosms than in the unvegetated mesocosms (Table 2).

Regardless of mesocosm type, $\mathrm{FeS}_{2}$ concentrations (0.0-18.0 $\left.\mathrm{mmol} \mathrm{g}^{-1} \mathrm{dw}\right)$ were lower than those of FeS (range: $0.4-29.8 \mu \mathrm{mol} \mathrm{g}^{-1} \mathrm{dw}$; Fig. 4e,f). Both FeS and $\mathrm{FeS}_{2}$ concentrations significantly changed with season, peaking during the summer and falling to their lowest levels during the winter (Table 2). The vegetated mesocosms had significantly smaller Fe sulfide pools than the unvegetated mesocosms (Table 2).

\section{Anaerobic metabolism}

CMR ranged from 68 to $90 \mathrm{mmol} \mathrm{m} \mathrm{m}^{-2} \mathrm{~d}^{-1}$ in the vegetated mesocosms and from 59 to $67 \mathrm{mmol} \mathrm{m}^{-2} \mathrm{~d}^{-1}$ in the unvegetated mesocosms; FeRR ranged from 95 to $170 \mathrm{mmol} \mathrm{m}^{-2} \mathrm{~d}^{-1}$ in the vegetated mesocosms and from 70 to $113 \mathrm{mmol} \mathrm{m}^{-2} \mathrm{~d}^{-1}$ in the unvegetated mesocosms; SRR ranged from 11 to $22 \mathrm{mmol} \mathrm{m}^{-2} \mathrm{~d}^{-1}$ in the vegetated mesocosms and from 13 to $20 \mathrm{mmol}$ $\mathrm{m}^{-2} \mathrm{~d}^{-1}$ in the unvegetated mesocosms (Fig. 5). The vegetated mesocosms had significantly higher CMR, FeRR, and SRR than the unvegetated mesocosms (Table 3). In both types of mesocosm, SRR peaked during the summer and was lowest in the winter, whereas FeRR exhibited the opposite trend. Season had a significant effect on CMR patterns in the vegetated mesocosm, but had no similar effect in the unvegetated mesocosm.

SRR in both types of mesocosm were correlated with temperature $\left(\mathrm{r}_{\text {vegetated }}=0.79, \mathrm{n}=21 ; \mathrm{r}_{\text {unvegetated }}=\right.$ $0.77, \mathrm{n}=21$ ), and SRR in the vegetated mesocosms were also correlated with the primary productivity of C. malaccensis $\left(\mathrm{r}_{\text {vegetated }}=0.88, \mathrm{n}=21\right)$. A stepwise multivariable linear regression analysis revealed that primary production accounted for comparable variation in SRR to temperature according to the standardized regression coefficients (Table 4). FeRR was negatively correlated with SRR in both types of mesocosm $\left(\mathrm{r}_{\text {vegetated }}=-0.80, \mathrm{n}=21 ; \mathrm{r}_{\text {unvegetated }}=-0.81\right.$, $\mathrm{n}=21$ ). There were no significant relationships between the SRR and FeRR and precipitation and inundation frequency.

\section{Contribution of anaerobic metabolism}

FeR accounted for 26 to $63 \%$ and from 27 to $47 \%$ of total CMR in the vegetated and unvegetated mesocosms, respectively, whereas the contribution of SR ranged from 32 to $53 \%$ and from 44 to $60 \%$ in the vegetated and unvegetated mesocosms, respectively 


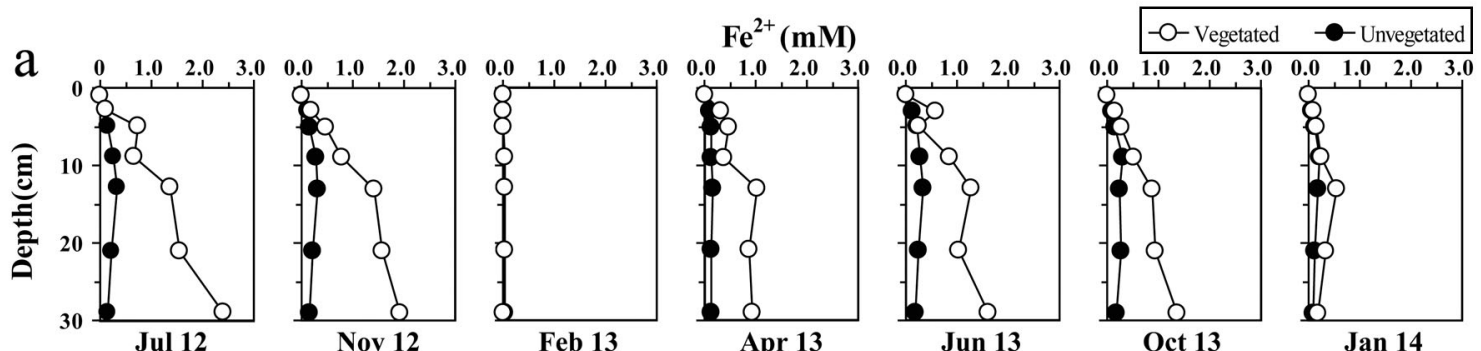

Non-sulfidic Fe(II) ( (n) $^{-1}$ dw)
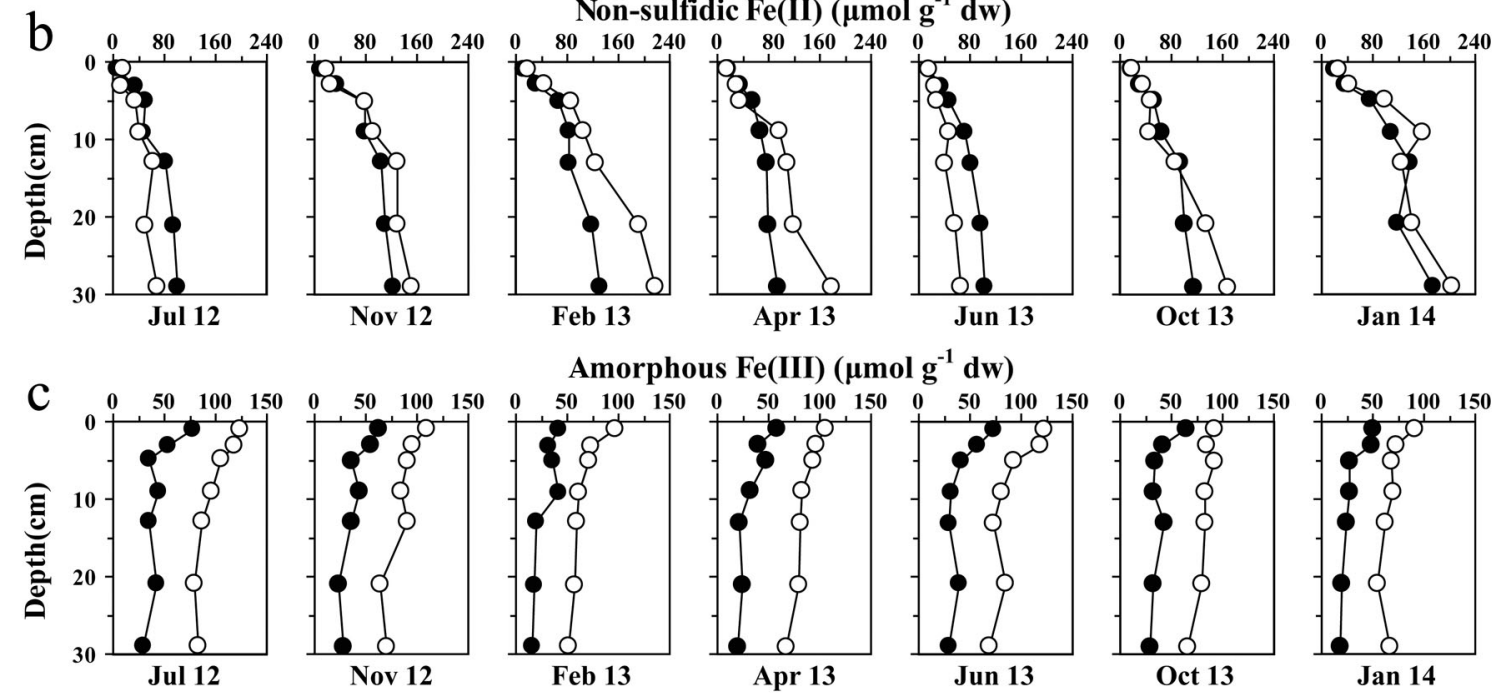

Amorphous Fe(III) ( $\left.\mu \mathrm{mol} \mathrm{g} \mathbf{g}^{-1} \mathrm{dw}\right)$
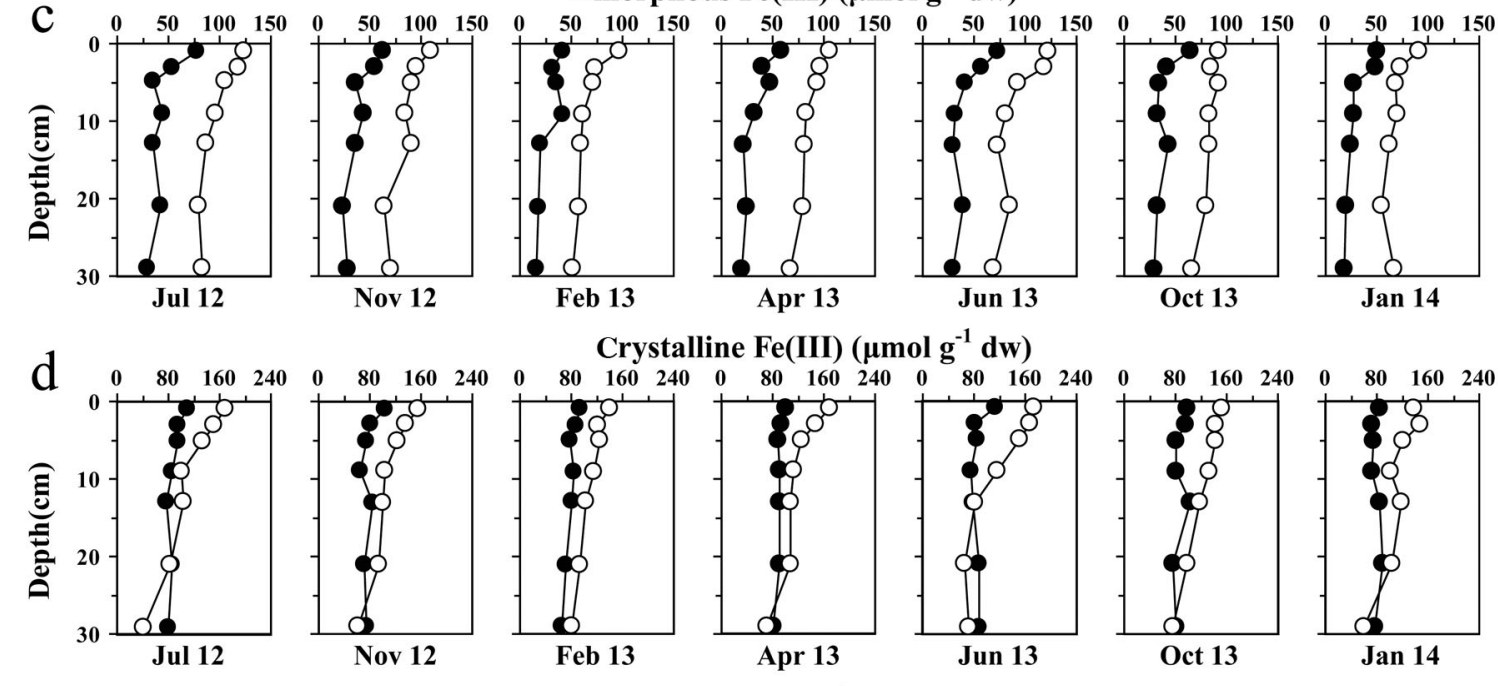

Crystalline Fe(III) ( $\left.\mu \mathrm{mol} \mathrm{g}^{-1} \mathrm{dw}\right)$
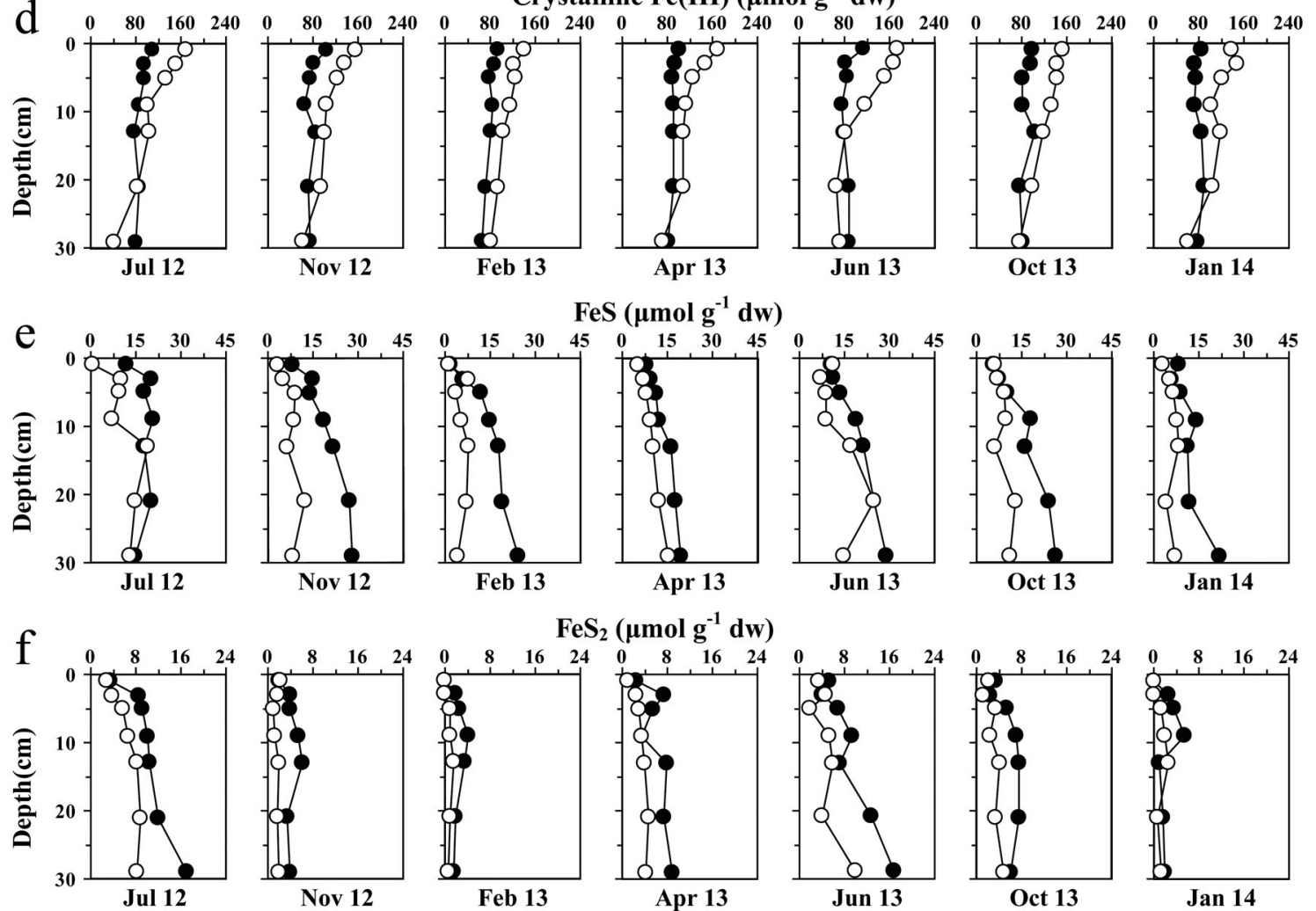

Jun 13

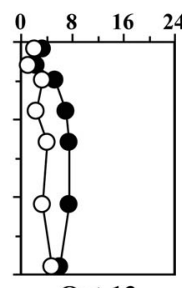

Oct 13

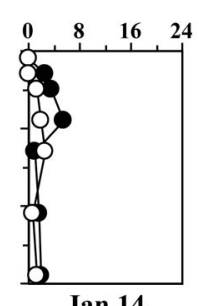

Fig. 4. Depth-specific iron (Fe) speciation in vegetated and unvegetated mesocosms in the tidal marsh sediments of the Min River estuary, East China Sea, during 2012-2014. (a) Porewater Fe ${ }^{2+}$, (b) non-sulfidic Fe(II), (c) amorphous Fe(III), (d) crystalline Fe(III), (e) FeS, and (f) $\mathrm{FeS}_{2}$ 


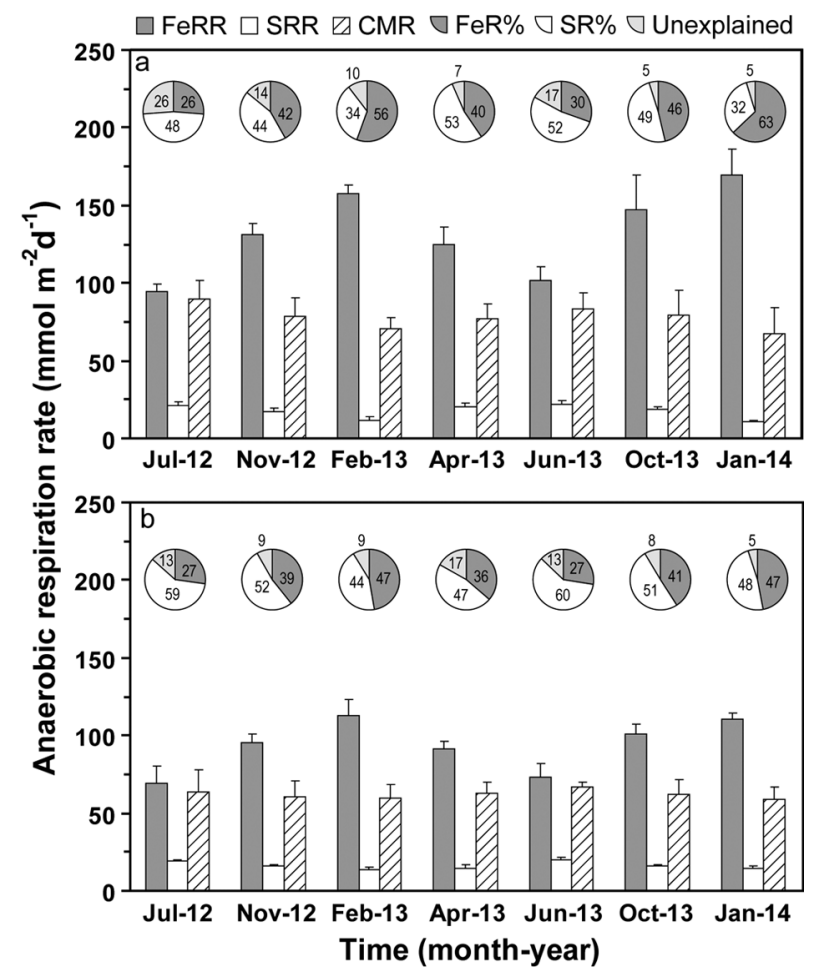

Fig. 5. Seasonal changes in depth-integrated rates of microbial iron reduction (FeRR), microbial sulfate reduction (SRR), and carbon mineralization (CMR) (bar charts); and FeR\%, $\mathrm{SR} \%$, and discrepancy (pie charts) in (a) vegetated and (b) unvegetated mesocosms in tidal marsh sediments of the Min River estuary, East China Sea, during 2012-2014. Unexplained proportion denotes a difference between $100 \%$ and $\mathrm{FeR} \%+\mathrm{SR} \%$. Error bars indicate SE
(Fig. 5). Both season and vegetation significantly affected FeR\% and SR\%, and accounted for $86 \%$ and $11 \%$ of $\mathrm{FeR} \%$ variability, respectively, whereas they accounted for $55 \%$ and $31 \%$ of SR\% variability, respectively (Table 3 ).

\section{DISCUSSION}

The mesocosm approach has previously been used for studying SR in saltmarsh and mangrove sediments (Gribsholt \& Kristensen 2002, Nielsen et al. 2003), as well as FeR in mangrove sediments (Kristensen \& Alongi 2006). However, to the best of our knowledge, this is the first time in situ mesocosms have been used to examine the role that sedge plants play in FeR in tidal marsh sediments.

\section{Seasonal change in anaerobic metabolism}

SR tracked seasonal temperature variations in all of the mesocosms. Similar seasonal trends in SR have been observed in other coastal systems, such as saltmarshes (Abdollahi \& Nedwell 1979, King 1988, Moeslund et al. 1994, Kostka et al. 2002a,b), mangrove forests (Holmer et al. 1999), and marine fish farms (Holmer \& Kristensen 1996). Warm seasons tend to support a greater $\mathrm{SO}_{4}{ }^{2-}$-reducing activity and

Table 3. Summary of a 2-way ANOVA of the effects of plant, season, and their interaction on inter-depth rates of microbial iron reduction rate (FeRR), microbial sulfate reduction rate (SRR), carbon mineralization (CMR), the contribution of iron reduction (FeR\%), and the contribution of sulfate reduction (SR\%) in the Min River estuary, East China Sea, during 2012-2014. Results in bold are statically significant $(\mathrm{p}<0.05)$

\begin{tabular}{|c|c|c|c|c|c|c|c|c|c|c|c|}
\hline \multirow[t]{2}{*}{ Source } & \multirow[t]{2}{*}{ df } & \multicolumn{2}{|c|}{- FeRR } & \multicolumn{2}{|c|}{$\longrightarrow$ SRR -} & \multicolumn{2}{|c|}{$-\mathrm{CMR}-$} & \multicolumn{2}{|c|}{$-\mathrm{FeR} \%$} & \multicolumn{2}{|c|}{$-\mathrm{SR} \%$} \\
\hline & & $F$ & $\mathrm{p}$ & $F$ & $\mathrm{p}$ & $F$ & $\mathrm{p}$ & $F$ & $\mathrm{p}$ & $F$ & $\mathrm{p}$ \\
\hline Plant & 1 & 90.281 & $<0.001$ & 12.994 & 0.001 & 25.143 & $<0.001$ & 5.795 & 0.022 & 8.024 & 0.008 \\
\hline Season & 3 & 36.999 & $<0.001$ & 39.590 & $<0.001$ & 2.780 & 0.056 & 47.167 & $<0.001$ & 14.086 & $<0.001$ \\
\hline Plant $\times$ Season & 3 & 2.967 & 0.046 & 6.913 & 0.001 & 0.718 & 0.548 & 1.602 & 0.207 & 3.446 & 0.027 \\
\hline Total & & 130.247 & & 59.497 & & 28.641 & & 54.564 & & 25.556 & \\
\hline$r^{2}$ & & 0.869 & & 0.813 & & 0.513 & & 0.819 & & 0.662 & \\
\hline
\end{tabular}

Table 4. Multiple regression parameters explaining the variance associated with microbial sulfate reduction rate (SRR). Adjusted $\mathrm{r}^{2}=0.735$. Multiple regression $F=38.866 ; \mathrm{p}<0.001$. Models were derived using the stepwise selection method and included seasonal (temperature and precipitation) and plant (above- and belowground biomasses, primary productivity, total organic carbon, total organic nitrogen, $\mathrm{C}: \mathrm{N}$ ratios, and integrated-depth dissolved organic carbon) components

\begin{tabular}{|lccrr|}
\hline $\begin{array}{l}\text { Response } \\
\text { variable }\end{array}$ & $\begin{array}{c}\text { Independent } \\
\text { variable }\end{array}$ & $\begin{array}{c}\text { Unstandardized regression } \\
\text { coefficient (mean } \pm \text { SE) }\end{array}$ & $\begin{array}{c}\text { Standardized regression } \\
\text { coefficient }\end{array}$ & $T$ \\
\hline SRR & (Constant) & $11.232 \pm 1.102$ & & 10.194 \\
& Temperature & $0.230 \pm 0.055$ & 0.412 & 4.190 \\
& Primary productivity & $0.455 \pm 0.099$ & 0.472 & $<0.001$ \\
& & & $<0.001$ \\
\hline
\end{tabular}


higher levels of bioavailable organic substrates than cold seasons (Howarth 1993, Holmer \& Kristensen 1996, Koretsky et al. 2003, Beck et al. 2008, Al-Raei et al. 2009). The large quantities of Fe sulfides and negative sediment $\Delta \mathrm{SO}_{4}{ }^{2-}$ observed in the present study also indicate that SR increased during the spring and summer (Figs. 3f \& 4e,f). In contrast, more positive sediment $\Delta \mathrm{SO}_{4}{ }^{2-}$ and smaller accumulations of $\mathrm{Fe}$ sulfides were observed during the autumn and winter (Fig. 3e), indicating that sulfide oxidation is stronger than SR in cold months (Howarth \& Giblin 1983, Hines et al. 1989, Hyun et al. 2007, Kostka et al. 2002a).

The inhibitory effect of increasing temperature on FeRR was clear in both types of mesocosm (Fig. 5), which was in contrast to simultaneous increases in Fe(III) oxide levels and organic substrate availability during warm months (Table 1, Figs. 3c \& 4c,d). This also disagrees with previous studies reporting increased growth of isolated Fe(III)-reducing microorganisms with increasing temperature (King \& Garey 1999, Meier et al. 2005). Furthermore, a positive correlation exists between electron acceptors or organic substrates and FeRR in freshwater systems (Roden \& Wetzel 1996, Neubauer et al. 2005) and rice wetlands (Yao \& Conrad 2000). However, a culture experiment on saltmarsh sediments collected from Sapelo Island, USA, provided results similar to ours (Koretsky et al. 2003). The same study showed that Fe(III)-reducing microorganisms were adversely affected by the addition of $\Sigma \mathrm{H}_{2} \mathrm{~S}$ (Koretsky et al. 2003). This is in accordance with the negative relationship observed between FeRR and SRR in both types of mesocosm in the present study. Importantly, both field and laboratory data support the sulfide-mediated limitation of FeR (Koretsky et al. 2003, 2005, Meier et al. 2005). How sulfides suppress FeR, even with abundant electron acceptors or organic substrates, is unclear. However, previous studies have found abundant $\mathrm{SO}_{4}{ }^{2-}$-reducing microorganisms in the tidal wetlands of the Min River estuary e.g. Desulfovibrio, Desulfobacterium, and Desulfobulbus (Tong et al. 2015), which can reduce $\mathrm{Fe}(\mathrm{III})$ and $\mathrm{SO}_{4}{ }^{2-}$ simultaneously (Lovley et al. 1993). Therefore, the inhibition of FeR by sulfides may also be caused by a shift in the microbial metabolic pathway (Weston et al. 2006), which means that more facultative microorganisms tend to use $\mathrm{SO}_{4}{ }^{2-}$ rather than $\mathrm{Fe}$ (III) in the presence of sulfides.

Previous studies have shown that the annual precipitation pattern over the course of a year (i.e. wet and dry seasons) also has a large impact on $\mathrm{Fe}$ and $\mathrm{S}$ biogeochemistry (Hines et al. 1989, Holmer et al.
1999, Kristensen et al. 2011, Nóbrega et al. 2013), given that the hydrology and hydroperiod of tidal marsh sediments are linked to oxygen $\left(\mathrm{O}_{2}\right)$ availability and redox conditions (Alongi 1995, Kostka \& Luther 1995, Holmer et al. 1999, Kostka et al. 2002a, Nóbrega et al. 2013). During the wet season, rainfall could dilute $\mathrm{SO}_{4}{ }^{2-}$ and thus suppress the activity of $\mathrm{SO}_{4}{ }^{2-}$-reducing microorganisms (Hines et al. 1989, Holmer et al. 1999, Alongi et al. 2001, Nóbrega et al. 2013). However, our results suggest that SRR and FeRR were similar in early spring $\left(15.2 \pm 2.0^{\circ} \mathrm{C}_{\text {; }}\right.$ precipitation: $122 \pm 21 \mathrm{~mm})$ and mid-autumn $(17.5 \pm$ $3.3^{\circ} \mathrm{C}$ i precipitation: $55 \pm 13 \mathrm{~mm}$ ), when temperatures were more or less similar but moisture regimes differed considerably (Fig. 5). These results, combined with the insignificant correlation observed between precipitation and both SRR and FeRR, suggest that these 2 anaerobic respiration rates in the tidal marsh sediments of the Min River estuary are less sensitive to changes in precipitation than to changes in temperature. This was most likely because our study site in the low-tide zone was inundated with seawater on a semi-daily basis, which may have offset any potential precipitation effects. Kostka \& Luther (1995) reported a similar pattern in the Great Marsh, Delaware, USA.

\section{Influence of plants on sediment geochemistry}

SRR in the vegetated mesocosms were correlated with both temperature and primary productivity. Temperature regulates SRR not only directly, but also indirectly via sedge plants, given that temperature is a key factor in controlling the physiological development of plants (Alongi et al. 2001, Koretsky et al. 2003). SRR were low in cold months, possibly because the Cyperus malaccensis plants had reached their frutescent and withering phases (September to February). During this period, plants generally allocate more organic matter to reproductive tissues or reduce exudations to withstand the cold, and consequently less plant-derived organic matter enters the sediment (Hines et al. 1999, Tobias \& Neubauer 2009; Table 1, Fig. 3c).

DOC is the main source of labile organic substrate for benthic microorganisms in tidal marshes (Hines et al. 1989, 1991, 1999). In addition to microbial hydrolysis and fermentation of organic matter, root exudates and detrital inputs also contribute to the DOC pools in the vegetated mesocosms (Holmer et al. 1999, Armstrong et al. 2000, Kristensen et al. 2000, 2011). This is probably the reason why the 
DOC pools were larger and exhibited greater fluctuations (due to constantly changing root activity) in the vegetated than in the unvegetated mesocosms (Fig. 3c). However, plant-derived DOC in the vegetated mesocosms may also have contained structural macromolecules (e.g. lignin), which would inhibit microbial respiration (Kristensen et al. 2008). Consequently, a certain fraction of low-quality DOC in the vegetated mesocosms may explain the lack of a clear relationship between respiration rates and the DOC pool.

$\mathrm{Fe}(\mathrm{III})$-reducing microorganisms in the vegetated mesocosms were provided with higher Fe(III) oxide concentrations than those in the unvegetated mesocosms (Fig. 4c,d). The initial Fe(III) pools were identical in the 2 kinds of mesocosm, but roots induce a progressive and long-term increase in Fe(III) oxides in rhizospheres due to radial $\mathrm{O}_{2}$ loss (Crowder \& StCyr 1991, Frenzel et al. 1999, Neubauer et al. 2008), which creates oxic and suboxic mosaics (Gribsholt \& Kristensen 2002, Holmer et al. 2002, Kostka et al. 2002a,b). The accumulated reduced Fe(II) is then reoxidized into a rusty-colored Fe plaque, which is composed of large amounts of amorphous Fe(III) and smaller amounts of crystalline Fe(III) (Weiss et al. 2004, 2005, Neubauer et al. 2008). Although Fe(III)reducing microorganisms can reduce a variety of Fe(III) oxide minerals, they prefer amorphous Fe(III) to crystalline Fe(III) because of the larger surface area of the former (Bonneville et al. 2009, Li et al. 2012). The importance of the mineralogical composition of Fe(III) oxides for FeR has been demonstrated in both field and laboratory settings (Weiss et al. 2004, Luo et al. 2015). In our experiment, $42 \pm 4 \%$ ( $\mathrm{n}=147$ ) of reactive Fe(III) (the sum of amorphous and crystalline $\mathrm{Fe}(\mathrm{III})$ ) in the vegetated mesocosms was amorphous $\mathrm{Fe}(\mathrm{III})$, but this proportion was only $30 \pm 3 \%(\mathrm{n}=147)$ in the unvegetated mesocosms. A relatively high abundance of amorphous Fe(III) may also account for the higher FeRR in the vegetated than in the unvegetated mesocosms.

Porewater $\mathrm{Fe}^{2+}$ levels were higher in the vegetated than in the unvegetated mesocosms during the sedge-growing seasons (Fig. 4a). One possible explanation for this is that Fe sulfides are oxidized by the $\mathrm{O}_{2}$ that is transported to the roots (Gribsholt \& Kristensen 2002, Holmer et al. 2002), which leads to an accumulation of porewater $\mathrm{Fe}^{2+}$ and an acidification of the sediments (Berner 1970, Luther \& Church 1988, Otero \& Macías 2002). This is in accordance with the fact that sulfide concentrations and the $\mathrm{pH}$ were lower in the vegetated than in the unvegetated mesocosms (Figs. 3a \& 4e,f). Another explanation is that higher DOC concentrations in the vegetated mesocosms resulted in higher levels of organic substrate adsorption onto amorphous Fe(III) under reducing conditions, which generated dissolved organic Fe(II) complexes (Jones et al. 2011). Dissolved organic Fe(II) complexes may be rapidly reoxidized by $\mathrm{O}_{2}$ or $\mathrm{Fe}(\mathrm{III})$ minerals and yield dissolved organic $\mathrm{Fe}(\mathrm{III})$ (Luther et al. 1992). Dissolved organic Fe(III) is a preferred electron acceptor for Fe(III)-reducing microorganisms, and it accelerated Fe cycling in the vegetated mesocosms because dissolved organic Fe(III) complexes are generally reduced more rapidly than solid-phase Fe(III) minerals (Beckler et al. 2015). Although dissolved organic Fe(III) was not measured in our study, relatively high concentrations of dissolved organic $\mathrm{Fe}(\mathrm{III})$ have been found in saltmarsh creek sediments in previous studies (Koretsky et al. 2008, Jones et al. 2011, Beckler et al. 2015).

\section{Total anaerobic metabolism}

Our results suggest that the dominant organic C mineralization pathway changed from SR in summer to FeR in winter in both vegetated and unvegetated mesocosms (Fig. 5). Similar seasonal trends in the partitioning between SR and FeR have been reported in the brackish marshes of the Patuxent River, Maryland, USA, and saltmarshes on Sapelo Island, Georgia, USA (Giblin \& Howarth 1984, Kostka et al. 2002a, Neubauer et al. 2005). However, the opposite trend was observed in a fresh tidal marsh on the Patuxent River, Maryland, USA (Neubauer et al. 2005), and in a freshwater wetland in Talladega, Alabama, USA (Roden \& Wetzel 1996). These discrepancies may have been caused by low levels of $\mathrm{SO}_{4}{ }^{2-}$ limiting SR in tidal freshwater marshes, and an insufficient generation of sulfides to inhibit FeR.

Our results also suggest that the presence of plants increases the competitiveness of $\mathrm{FeR} \%$ and lowers $\mathrm{SR} \%$, which is in accordance with that found in other studies, including mangrove mesocosms in North Queensland, Australia (Kristensen \& Alongi 2006), tidal marshes on Sapelo Island, USA (Kostka et al. 2002a) and Skidaway Island, USA (Hyun et al. 2007), Han River estuary, Korea (Hyun et al. 2009), Patuxent River, USA (Neubauer et al. 2005), and mangrove forests on Phuket Island, Thailand (Kristensen et al. 2000).

Both FeRR and SRR may be underestimated in sealed laboratory incubations, because the rapid reoxidation of $\mathrm{Fe}(\mathrm{II})$ and sulfides by sedge root activity, advective groundwater processes, and tidal 
pumping are not taken into account (Kristensen et al. 2000, 2011, Tallifert et al. 2007, Beckler et al. 2015). In addition, dissolved organic substrate-mediated $\mathrm{Fe}(\mathrm{II})-\mathrm{Fe}(\mathrm{III})$ cycling cannot occur in closed containers because roots are excluded (Beckler et al. 2015).

When combined, $\mathrm{FeR} \%$ and SR\% on average accounted for $88 \pm 5 \%$ of total anaerobic organic C mineralization in the 2 types of mesocosm (Fig. 5). The unexplained proportion may have been caused by underestimated SR\% in both types of mesocosm, but particularly for the vegetated mesocosms due to rapid sulfide reoxidation (Luo et al. 2016). The unexplained proportion might also have been caused by $\mathrm{CO}_{2}$ formation via fermentation (Jørgensen 2000, Hyun et al. 2009) or by other terminal electronaccepting processes, such as denitrification and manganese $(\mathrm{Mn})$ reduction. However, the contributions of $\mathrm{NO}_{3}{ }^{-}$and $\mathrm{Mn}(\mathrm{IV})$ to organic $\mathrm{C}$ mineralization may have been small, because their concentrations are much lower than concentrations of $\mathrm{SO}_{4}{ }^{2-}$ and $\mathrm{Fe}(\mathrm{III})$ in sediments of the Min River estuary tidal marsh (Luo et al. 2014).

\section{CONCLUSIONS}

Comparative data collected from in situ vegetated and unvegetated mesocosms from 2012 to 2014 clearly demonstrate that seasonal change and the presence of plants both have an effect on Fe cycling and the organic $\mathrm{C}$ mineralization pathway in tidal marsh sediments of the Min River estuary. A shift in the dominant organic matter mineralization pathway from SR in summer to FeR in winter occurred in both the vegetated and unvegetated mesocosms. The presence of sedge plants reduced the relative importance of SR in favor of FeR as the primary organic C mineralization pathway. When directly compared, seasonal change clearly had a more pronounced effect on the organic $C$ mineralization pathway than the presence of plants. SR influenced FeR in both vegetated and unvegetated mesocosms, while $\mathrm{SR}$ variability was mainly caused by seasonal cycles of temperature and primary productivity. In addition to temperature, precipitation, and plants, other factors not examined here, including light intensity, tidal flushing, salinity, bioturbation, freshwater inputs, artificial interference, typhoons, alien species invasions, and sea-level rises, may also affect the dynamics of plant-mediated processes and oxidative events in tidal marsh sediments. Therefore, redox-mediated Fe dynamics should be further investigated in future studies.
Acknowledgements. We thank the Contributing Editor, Erik Kristensen and 2 anonymous reviewers for their valuable comments and suggestions which improved the manuscript. We thank Elsevier WebShop for its linguistic assistance during the preparation of this manuscript. This study was financially supported by the National Science Foundation of China (Grant No. 41501252), the Science Foundation of Fujian Province (Grant No. 2016J05097), China Postdoctoral Science Foundation (2016M602052), the Program for Innovative Research Team at Fujian Normal University (IRTL1205), and the Scientific Research Foundation of Fuzhou University (XRC-1521).

\section{LITERATURE CITED}

Abdollahi H, Nedwell DB (1979) Seasonal temperature as a factor influencing bacterial sulfate reduction in a saltmarsh sediment. Microb Ecol 5:73-79

Al-Raei AM, Bosselmann K, Böttcher ME, Hespenheide B, Tauber F (2009) Seasonal dynamics of microbial sulfate reduction in temperate intertidal surface sediments: controls by temperature and organic matter. Ocean Dyn 59: 351-370

Alongi DM (1995) Effect of monsoonal climate on sulfate reduction in coastal sediments of the central Great Barrier Reef lagoon. Mar Biol 122:497-502

Alongi DM, Wattayakorn G, Pfitzner J, Tirendi F and others (2001) Organic carbon accumulation and metabolic pathways in sediments of mangrove forests in southern Thailand. Mar Geol 179:85-103

APHA (American Public Health Association) (2005) Standard methods for the examination of water and wastewater. American Public Health Association, Washington, DC

Armstrong W, Cousins D, Armstrong J, Turner D, Beckett P (2000) Oxygen distribution in wetland plant roots and permeability barriers to gas-exchange with the rhizosphere: a microelectrode and modelling study with Phragmites australis. Ann Bot 86:687-703

Beck M, Dellwig O, Holstein JM, Grunwald M, Liebezeit G, Schnetger B, Brumsack HJ (2008) Sulphate, dissolved organic carbon, nutrients and terminal metabolic products in deep pore waters of an intertidal flat. Biogeochemistry 89:221-238

Beckler JS, Jones ME, Taillefert M (2015) The origin, composition, and reactivity of dissolved iron (III) complexes in coastal organic- and iron-rich sediments. Geochim Cosmochim Acta 152:72-88

Berner RA (1970) Sedimentary pyrite formation. Am J Sci 268:1-23

Bonneville S, Behrends T, Van Cappellen P (2009) Solubility and dissimilatory reduction kinetics of iron(III) oxyhydroxides: a linear free energy relationship. Geochim Cosmochim Acta 73:5273-5282

Böttcher ME, Schale H, Schnetger B, Wallmann K, Brumsack HJ (2000) Stable sulfur isotopes indicate net sulfate reduction in near-surface sediments of the deep Arabian Sea. Deep-Sea Res II 47:2769-2783

Bull D, Taillefert M (2001) Environmental and seasonal variations in porewaters of a southeastern USA salt marsh as revealed by voltammetric microelectrode profiling. Geochem Trans 13:1-8

* Burton ED, Sullivan LA, Bush RT, Johnston SG, Keene AF (2008) A simple and inexpensive chromium-reducible 
sulfur method for acid-sulfate soils. Appl Geochem 23: 2759-2766

Canfield DE (1989) Reactive iron in marine sediments. Geochim Cosmochim Acta 53:619-632

Cline JD (1969) Spectrophotometric determination of hydrogen sulfide in natural waters. Limnol Oceanogr 14: 454-458

Crowder A, St-Cyr L (1991) Iron oxide plaque on wetland roots. Trends Soil Sci 1:315-329

Dame R, Kenny PD (1986) Variability of Spartina alterniflora primary production in the euhaline North Inlet estuary. Mar Ecol Prog Ser 32:71-80

Ding Y, Chan JCL (2005) The East Asian summer monsoon: an overview. Meteorol Atmos Phys 89:117-142

Ferreira T, Otero X, Vidal-Torrado P, Macías F (2007) Effects of bioturbation by root and crab activity on iron and sulfur biogeochemistry in mangrove substrate. Geoderma 142:36-46

Frenzel P, Bosse U, Janssen PH (1999) Rice roots and methanogenesis in a paddy soil: ferric iron as an alternative electron acceptor in the rooted soil. Soil Biol Biochem 31: 421-430

Giblin AE, Howarth RW (1984) Porewater evidence for a dynamic sedimentary iron cycle in salt marshes. Limnol Oceanogr 29:47-63

Gribsholt B, Kristensen E (2002) Effects of bioturbation and plant roots on salt marsh biogeochemistry: a mesocosm study. Mar Ecol Prog Ser 241:71-87

Hines ME, Knollmeyer SL, Tugel JB (1989) Sulfate reduction and other sedimentary biogeochemistry in a northern New England salt marsh. Limnol Oceanogr 34:578-590

Hines ME, Bazylinski DA, Tugel JB, Lyons WB (1991) Anaerobic microbial biogeochemistry in sediments from two Basins in the Gulf of Maine: evidence for iron and manganese reduction. Estuar Coast Shelf Sci 32:313-324

Hines ME, Evans RS, Genthner BRS, Willis SG and others (1999) Molecular phylogenetic and biogeochemical studies of sulfate-reducing bacteria in the rhizosphere of Spartina alterniflora. Appl Environ Microbiol 65: 2209-2216

Holmer M, Kristensen E (1996) Seasonality of sulfate reduction and pore water solutes in a marine fish farm sediment: the importance of temperature and sedimentary organic matter. Biogeochemistry 32:15-39

*Holmer M, Andersen FØ, Holmboe N, Kristensen E, Thongtham N (1999) Transformation and exchange processes in the Bangrong mangrove forest-seagrass bed system, Thailand. Seasonal and spatial variations in benthic metabolism and sulfur biogeochemistry. Aquat Microb Ecol 20:203-212

Holmer M, Gribsholt B, Kristensen E (2002) Effects of sea level rise on growth of Spartina anglica and oxygen dynamics in rhizosphere and salt marsh sediments. Mar Ecol Prog Ser 225:197-204

Howarth RW (1993) Microbial processes in salt-marsh sediments. In: Ford TE (ed) Aquatic microbiology: an ecological application. Blackwell, Malden, MA, p 239-259

*Howarth RW, Giblin A (1983) Sulfate reduction in the salt marshes at Sapelo Island, Georgia. Limnol Oceanogr 28: 70-82

* Huerta-Diaz MA, Morse JW (1992) Pyritization of trace metals in anoxic marine sediments. Geochim Cosmochim Acta 56:2681-2702

Hyun JH, Smith AC, Kostka JE (2007) Relative contributions of sulfate- and iron(III) reduction to organic matter min- eralization and process controls in contrasting habitats of the Georgia saltmarsh. Appl Geochem 22:2637-2651

*Hyun JH, Mok JS, Cho HY, Kim SH, Lee KS, Kostka JE (2009) Rapid organic matter mineralization coupled to iron cycling in intertidal mud flats of the Han River estuary, Yellow Sea. Biogeochemistry 92:231-245

*Johnston SG, Keene AF, Bush RT, Burton ED and others (2011) Iron geochemical zonation in a tidally inundated acid sulfate soil wetland. Chem Geol 280:257-270

Jones ME, Beckler JS, Taillefert M (2011) The flux of soluble organic-iron(III) complexes from sediments represents a source of stable iron(III) to estuarine waters and to the continental shelf. Limnol Oceanogr 56:1811-1823

Jørgensen BB (2000) Bacteria and marine biogeochemistry. In: Schulz HD, Zobel M (eds) Marine geochemistry. Springer, Berlin, p 173-207

KKing GM (1988) Patterns of sulfate reduction and the sulfur cycle in a South Carolina salt marsh. Limnol Oceanogr 33:376-390

King GM, Garey MA (1999) Ferric iron reduction by bacteria associated with the roots of freshwater and marine macrophytes. Appl Environ Microbiol 65:4393-4398

Koretsky CM, Moore CM, Lowe KL, Meile C, DiChristina TJ, Van Cappellen P (2003) Seasonal oscillation of microbial iron and sulfate reduction in saltmarsh sediments (Sapelo Island, GA, USA). Biogeochemistry 64:179-203

Koretsky CM, Van Cappellen P, DiChristina TJ, Kostka JE and others (2005) Salt marsh pore water geochemistry does not correlate with microbial community structure. Estuar Coast Shelf Sci 62:233-251

Koretsky CM, Cuellar A, Haveman M, Beuving L, Shattuck T, Wagner M (2008) Influence of Spartina and Juncus on saltmarsh sediments. II. Trace element geochemistry. Chem Geol 255:100-113

Kostka JE, Luther GW III (1994) Partitioning and speciation of solid phase iron in saltmarsh sediments. Geochim Cosmochim Acta 58:1701-1710

Kostka JE, Luther GW III (1995) Seasonal cycling of Fe in saltmarsh sediments. Biogeochemistry 29:159-181

* Kostka JE, Gribsholt B, Petrie E, Dalton D, Skelton H, Kristensen E (2002a) The rates and pathways of carbon oxidation in bioturbated saltmarsh sediments. Limnol Oceanogr 47:230-240

Kostka JE, Roychoudhury A, Van Cappellen P (2002b) Rates and controls of anaerobic microbial respiration across spatial and temporal gradients in saltmarsh sediments. Biogeochemistry 60:49-76

Kristensen E (2001) Impact of polychaetes (Nereis spp. and Arenicola marina) on carbon biogeochemistry in coastal marine sediments. Geochem Trans 2:92

Kristensen E, Alongi DM (2006) Control by fiddler crabs (Uca vocans) and plant roots (Avicennia marina) on carbon, iron, and sulfur biogeochemistry in mangrove sediment. Limnol Oceanogr 51:1557-1571

Kristensen E, Andersen F, Holmboe N, Holmer M, Thongtham N (2000) Carbon and nitrogen mineralization in sediments of the Bangrong mangrove area, Phuket, Thailand. Aquat Microb Ecol 22:199-213

Kristensen E, Bouillon S, Dittmar T, Marchand C (2008) Organic carbon dynamics in mangrove ecosystems: a review. Aquat Bot 89:201-219

Kristensen E, Mangion P, Tang M, Flindt MR, Holmer M, Ulomi S (2011) Microbial carbon oxidation rates and pathways in sediments of two Tanzanian mangrove forests. Biogeochemistry 103:143-158 
Li X, Liu T, Li F, Zhang W, Zhou S, Li Y (2012) Reduction of structural Fe(III) in oxyhydroxides by Shewanella decolorationis $\mathrm{S} 12$ and characterization of the surface properties of iron minerals. J Soils Sediments 12:217-227

Lovley DR, Phillips EJ (1986) Organic matter mineralization with reduction of ferric iron in anaerobic sediments. Appl Environ Microbiol 51:683-689

Lovley DR, Roden EE, Phillips EJP, Woodward JC (1993) Enzymatic iron and uranium reduction by sulfate-reducing bacteria. Mar Geol 113:41-53

Luo M, Zeng CS, Tong C, Huang JF, Yu Q, Guo YB, Wang $\mathrm{SH}$ (2014) Abundance and speciation of iron across a subtropical tidal marsh of the Min River Estuary in the East China Sea. Appl Geochem 45:1-13

Luo M, Zeng CS, Tong C, Huang JF, Yu Q, Guo YB, Wang SH (2015) Kinetics of chemical and microbial iron reduction along an inundation gradient in a tidal marsh of the Min River Estuary, Southeastern China. Geomicrobiol J 32:635-647

Luo M, Zeng CS, Tong C, Huang JF, Chen K, Liu FQ (2016) Iron reduction along an inundation gradient in a tidal sedge (Cyperus malaccensis) marsh: the rates, pathways, and contributions to anaerobic organic matter mineralization. Estuaries Coasts 39:1679-1693

Luther GW III, Church TM (1988) Seasonal cycling of sulfur and iron in porewaters of a Delaware salt marsh. Mar Chem 23:295-309

Luther GW III, Kostka JE, Church TM, Sulzberger B, Stumm W (1992) Seasonal iron cycling in the salt-marsh sedimentary environment: the importance of ligand complexes with $\mathrm{Fe}$ (II) and Fe (III) in the dissolution of Fe (III) minerals and pyrite, respectively. Mar Chem 40:81-103

Meier J, Costa R, Smalla K, Boehrer B, Wendt-Potthoff K (2005) Temperature dependence of Fe(III) and sulfate reduction rates and its effect on growth and composition of bacterial enrichments from an acidic pit lake neutralization experiment. Geobiology 3:261-274

Mitsch WJ, Gosselink JG (2000) The value of wetlands: importance of scale and landscape setting. Ecol Econ 35: 25-33

Moeslund L, Thamdrup B, Jørgensen BB (1994) Sulfur and iron cycling in a coastal sediment: radiotracer studies and seasonal dynamics. Biogeochemistry 27:129-152

Neubauer SC, Givler K, Valentine S, Megonigal JP (2005) Seasonal patterns and plant-mediated controls of subsurface wetland biogeochemistry. Ecology 86:3334-3344

Neubauer S, Emerson D, Megonigal J (2008) Microbial oxidation and reduction of iron in the root zone and influences on metal mobility. John Wiley \& Sons, Hoboken, NJ, p 339-371

Nielsen OI, Kristensen E, Macintosh DJ (2003) Impact of fiddler crabs (Uca spp.) on rates and pathways of benthic mineralization in deposited mangrove shrimp pond waste. J Exp Mar Biol Ecol 289:59-81

* Nóbrega GN, Ferreira TO, Romero RE, Marques AGB, Otero XL (2013) Iron and sulfur geochemistry in semiarid mangrove soils (Ceará, Brazil) in relation to seasonal changes and shrimp farming effluents. Environ Monit

Editorial responsibility: Erik Kristensen, Odense, Denmark
Assess 185:7393-7407

* Otero XL, Macías F (2002) Spatial and seasonal variation in heavy metals in interstitial water of salt marsh soils. Environ Pollut 120:183-190

Koden EE, Wetzel RG (1996) Organic carbon oxidation and suppression of methane production by microbial Fe(III) oxide reduction in vegetated and unvegetated freshwater wetland sediments. Limnol Oceanogr 41: 1733-1748

Sarazin G, Michard G, Prevot F (1999) A rapid and accurate spectroscopic method for alkalinity measurements in sea water samples. Water Res 33:290-294

* Schubauer JP, Hopkinson CS (1984) Above- and belowground emergent macrophytes production and turnover in a coastal marsh ecosystem, Georgia. Limnol Oceanogr 29:1052-1065

Stumm W, Morgan JJ (1996) Chemical thermodynamics and kinetics. In: Schnoor JL, Zehnder A (eds) Aquatic chemistry. Wiley, New York, NY, p 16-87

* Thamdrup B, Glud RN, Hansen JW (1994) Manganese oxidation and in situ manganese fluxes from a coastal sediment. Geochim Cosmochim Acta 58:2563-2570

Tobias CR, Neubauer SC (2009) Salt marsh biogeochemistry-an overview. In: Perillo GME, Wolanski E, Cahoon DR, Brinson MM (eds) Coastal wetlands: an integrated ecosystem approach. Elsevier, Amsterdam, p 445-492

* Tong C, Wang W, Zeng C, Marrs R (2010) Methane $\left(\mathrm{CH}_{4}\right)$ emission from a tidal marsh in the Min River estuary, southeast China. J Environ Sci Health A Tox Hazard Subst Environ Eng 45:506-516

Tong C, She CX, Yang P, Jin YF, Huang JF (2015) Weak correlation between methane production and abundance of methanogens across three brackish marsh zones in the Min River Estuary, China. Estuar Coast 38:1872-1884

Wang WQ, Sardans J, Wang C, Zeng CS, Tong C, Asensio D, Peñuelas J (2015) Ecological stoichiometry of C, N, and $\mathrm{P}$ of invasive Phragmites australis and native Cyperus malaccensis species in the Minjiang River tidal estuarine wetlands of China. Plant Ecol 216: 809-822

*Weiss JV, Emerson D, Megonigal JP (2004) Geochemical control of microbial Fe(III) reduction potential in wetlands: comparison of the rhizosphere to non-rhizosphere soil. FEMS Microbiol Ecol 48:89-100

*Weiss JV, Emerson D, Megonigal JP (2005) Rhizosphere iron (III) deposition and reduction in a Juncus effusus L.-dominated wetland. Soil Sci Soc Am J 69:1861-1870

Weston NB, Dixon RE, Joye SB (2006) Ramifications of increased salinity in tidal freshwater sediments: geochemistry and microbial pathways of organic matter mineralization. J Geophys Res 111:G01009

Yao H, Conrad R (2000) Effect of temperature on reduction of iron and production of carbon dioxide and methane in anoxic wetland rice soils. Biol Fertil Soils 32:135-141

Zhang LH, Zeng CS, Tong C (2008) Study on biomass dynamics of Phragmites australis and Spartina alterniflora in the wetlands of Minjiang River Estuary. J Subtrop Resour Environ 3:25-33

Submitted: December 19, 2016; Accepted: July 20, 2017

Proofs received from author(s): August 12, 2017 